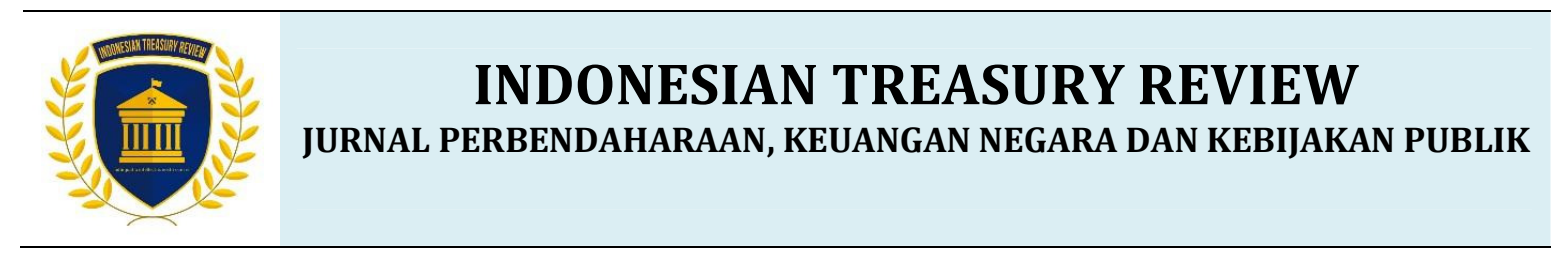

\title{
POTENSI DAN STRATEGI PENERBITAN BLUE SUKUK
}

\author{
Eri Hariyanto \\ Badan Pendidikan dan Pelatihan Keuangan \\ Alamat korespondensi: erihariyanto@gmail.com
}

\begin{abstract}
The implementation of a deficit budget policy encourages the government to innovate sources of financing. Among these innovations is the issuance of Sukuk Negara. The role of the Sukuk Negara to be encouraged in order to make a greater contribution to development. On the other side the Government is also faced with realizing the Sustainable Development Goals (SDGs) in 2030. One of the seventeen development goals is to protect marine resources. The challenges of sustainable development on the other hand become an opportunity for the Government to develop financing instruments for the marine sector. This challenge is an opportunity for the issuance of Blue Sukuk. Researchers examined the opportunity for the issuance of Blue Sukuk by using two methods, namely Regulatory Impact Analysis (RIA) and Strength Weakness Opportunity and Threat (SWOT) Analysis. Comparison of benefits and costs in the RIA method resulting in values> 1 means that the issuance of Blue Sukuk is feasible. While the SWOT analysis shows the strength and opportunity are more dominant than other factors. Based on this, the strategy to be implemented is to identify the absorption capacity of domestic and global financial markets to find out the potential of Blue Sukuk investors.
\end{abstract}

KATA KUNCI:

Blue Sukuk, pembiayaan defisit, sektor kelautan, pembangunan berkelanjutan

\begin{abstract}
ABSTRAK
Penerapan kebijakan anggaran defisit mendorong pemerintah melakukan inovasi sumber pembiayaan. Di antara inovasi tersebut adalah penerbitan Sukuk Negara. Peran Sukuk Negara terus didorong agar memberikan kontribusi yang lebih besar bagi pembangunan. Di sisi lain Pemerintah juga dihadapkan untuk mewujudkan tujuan pembangunan berkelanjutan (Sustainable Development Goals/SDGs) pada tahun 2030. Satu di antara tujuh belas tujuan pembangunan tersebut adalah menjaga sumber daya laut. Tantangan pembangunan berkelanjutan ini di sisi lain menjadi peluang Pemerintah untuk mengembangkan instrumen pembiayaan bagi sektor kelautan. Tantangan ini menjadi peluang bagi penerbitan Blue Sukuk. Peneliti mengkaji peluang penerbitan Blue Sukuk dengan menggunakan dua metode yaitu Regulatory Impact Analysis (RIA) dan Strength Weakness Opportunity and Threat (SWOT) Analysis. Perbandingan manfaat dan biaya dengan metode RIA menghasilkan nilai $>1$ berarti penerbitan Blue Sukuk layak untuk dilakukan. Sedangkan analisis SWOT menunjukkan sisi kekuatan dan peluang lebih dominan dibandingkan faktor lainnya. Berdasarkan hal tersebut maka strategi yang ditempuh adalah melakukan identifikasi daya serap pasar keuangan domestik dan global untuk mengetahui potensi investor Blue Sukuk.
\end{abstract}

\section{KLASIFIKASI JEL:}

H63

CARA MENGUTIP:

Hariyanto, E. (2020). Potensi dan strategi penerbitan blue sukuk. Indonesian Treasury Review: Jurnal Perbendaharaan, Keuangan Negara dan Kebijakan Publik, 5(2), 151-170. 


\section{PENDAHULUAN}

\subsection{Latar Belakang}

Dalam rangka mendorong pertumbuhan ekonomi yang lebih tinggi, Pemerintah menerapkan sistem anggaran defisit beberapa tahun terakhir. Dengan menggunakan sistem ini, Pemerintah dapat mengalokasikan belanja negara yang lebih besar dari pendapatan negara. Pengalokasian belanja Pemerintah yang lebih besar diharapkan dapat mendorong aktivitas perekonomian berupa penyediaan barang dan jasa yang lebih banyak. Selisih negatif antara pendapatan dan belanja negara tersebut, yang disebut sebagai defisit, dibiayai dengan berbagai instrumen pembiayaan diantaranya melalui pinjaman langsung (direct loan) dan penerbitan Government Securities atau Surat Berharga Negara (SBN).

Peran pembiayaan dalam Anggaran Pendapatan dan Belanja Negara (APBN) setidaknya dalam jangka waktu 5 tahun terakhir semakin meningkat. Indikator meningkatnya peran pembiayaan tersebut dapat dilihat dari semakin meningkatnya realisasi defisit APBN dari tahun ke tahun, sebagaimana gambar di bawah ini:

Gambar 1. Defisit dan Pembiayaan APBN 2012 s.d. 2018

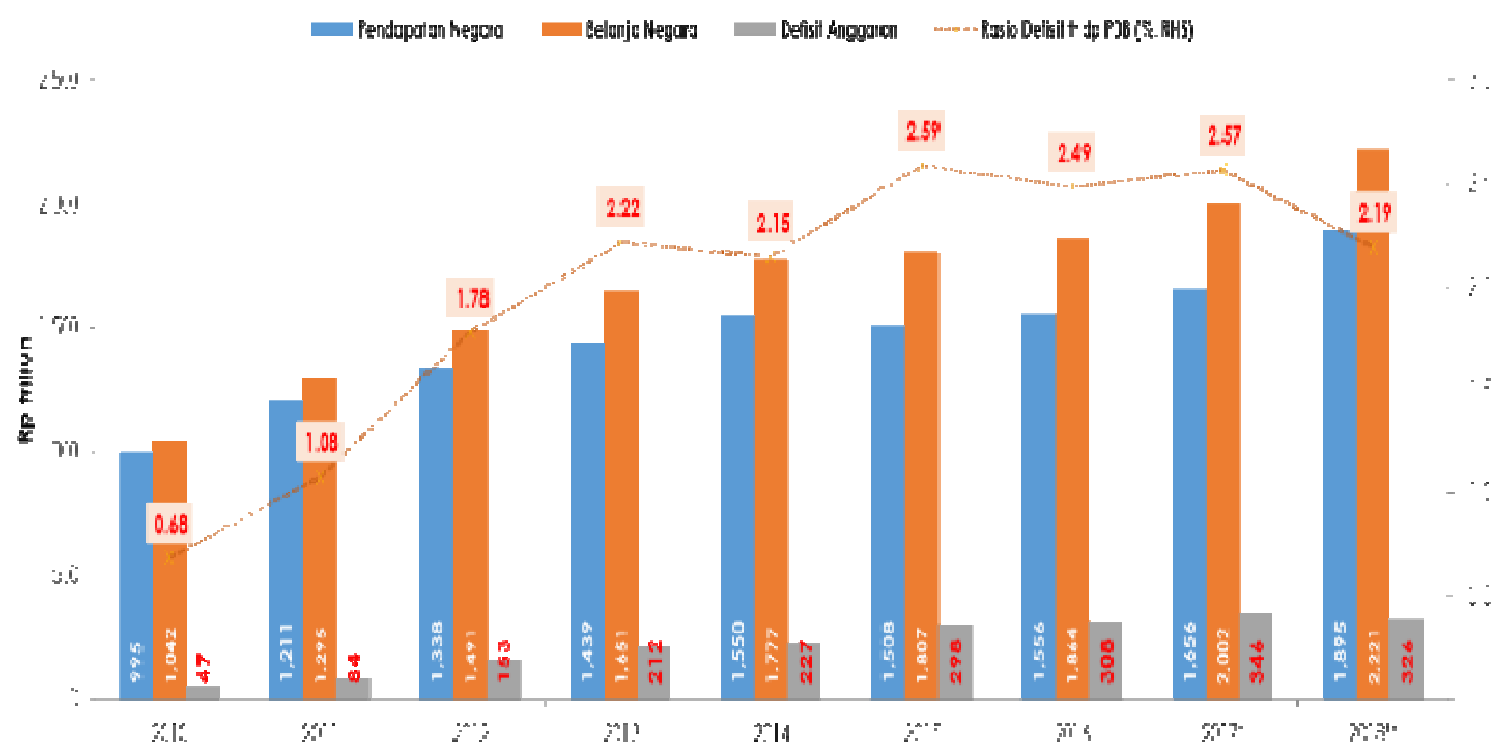

Sumber: Slide Presentasi DJPPR, 2018

Berdasarkan gambar di atas, dapat diketahui bahwa defisit APBN cenderung mengalami peningkatan sehingga memerlukan penambahan jumlah pembiayaan dari tahun ke tahun. Pada periode tahun 2014 s.d. 2015 terjadi peningkatan jumlah defisit APBN yang cukup siginifikan yaitu sebesar 0,4\% Produk Domestik Bruto (PDB). Hal ini menimbulkan konsekuensi peningkatan penerbitan SBN sebesar Rp97 triliun. Berdasarkan
Nota Keuangan Tahun 2019, peningkatan utang Pemerintah dalam 5 tahun terakhir disebabkan oleh kombinasi kebijakan defisit yang bertujuan untuk memacu pembangunan infrastruktur dan melemahnya kondisi perekonomian dunia yang berdampak terhadap berkurangnya penerimaan pendapatan negara.

Seiring meningkatnya tren pembiayaan, Pemerintah juga terus mengembangkan berbagai instrumen pembiayaan. Di antara inovasi pengembangan instrumen pembiayaan yang dilakukan adalah dengan menerbitkan Surat Berharga Negara (SBN) berbasis syariah, yaitu Surat Berharga Syariah Negara (SBSN) atau Sukuk Negara. Inovasi ini dilakukan selain untuk mengembangkan instrumen pembiayaan dan perluasan basis investor, juga sebagai respon atas berkembangnya industri keuangan syariah di dalam negeri maupun internasional.

Perkembangan industri keuangan syariah tersebut tentu membutuhkan instrumen investasi yang sesuai dengan prinsip syariah sebagai sarana untuk mengembangkan aset keuangan yang dimiliki.

Penyediaan instrumen keuangan syariah oleh Pemerintah tentu akan menjadi pilihan utama para pelaku industri keuangan syariah karena goverment securities adalah instrumen investasi dengan risiko minimal (zero risk).

Penerbitan Sukuk Negara sampai saat ini menunjukkan perkembangan yang sangat baik. Pada bulan Agustus 2008 Pemerintah mengawali penerbitan Sukuk Negara dengan nilai Rp4,8 triliun. Jumlah penerbitan Sukuk Negara dari tahun ke tahun semakin meningkat, seiring dengan pertumbuhan nominal APBN. Pada bulan Juli 2019 total penerbitan Sukuk Negara telah mencapai 
Rp1.143, 5 triliun, dengan nilai outstanding Rp645, 9 triliun. Adapun rincian penerbitan Sukuk Negara sejak tahun 2008 tersaji dalam tabel di bawah ini:

\section{Tabel 1. Total Penerbitan Sukuk Negara s.d.} Juli 2019

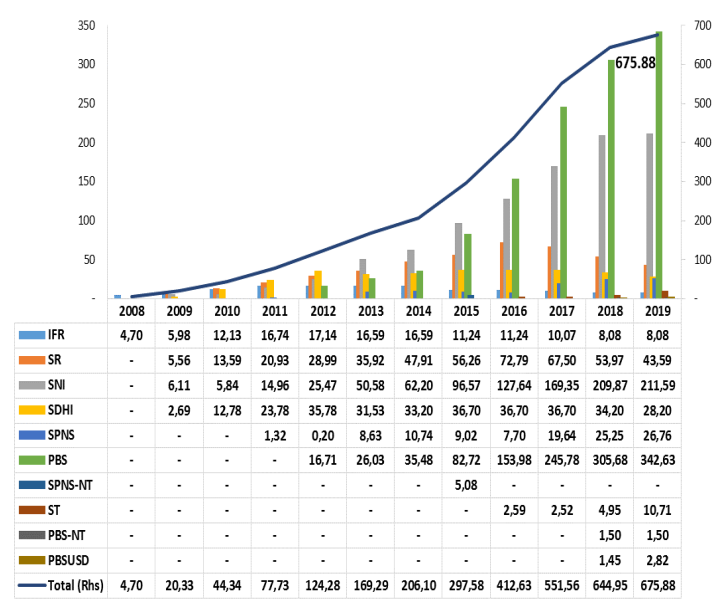

Sumber: DJPPR, 2019

Berdasarkan tabel di atas dapat dilihat bahwa penerbitan Sukuk Negara terus mengalami peningkatan gradual dari tahun ke tahun. Komite Nasional Keuangan Syariah (KNKS) yang dibentuk melalui Peraturan Presiden Nomor 91 Tahun 2016 tentang Komite Nasional Keuangan Syariah, menargetkan agar peran Sukuk Negara dalam pembiayaan defisit APBN dapat semakin meningkat. Pada masa mendatang, KNKS menargetkan penerbitan Sukuk Negara dapat menyamai jumlah penerbitan Obligasi Negara konvensional (setidaknya 50\% defisit APBN dibiayai melalui penerbitan Sukuk Negara).

Tantangan ini tentu tidak mudah untuk dilaksanakan. Pemerintah harus menjaga agar iklim ekonomi makro dan kondisi fiskal yang baik untuk mendukung penerbitan Sukuk Negara, serta melakukan inovasi dalam menciptakan jenis-jenis Sukuk Negara baru yang dapat diterima oleh investor, sehingga pasar Sukuk Negara dapat terus berkembang. Perbedaaan utama antara Sukuk Negara dan Obligasi Negara adalah penggunaan underlying asset dalam penerbitan Sukuk Negara. Pengembangan instrumen Sukuk Negara, berarti sama dengan pengembangan jenis underlying asset untuk penerbitan Sukuk Negara.

Seri-seri Sukuk Negara tersebut saat ini menggunakan 3 jenis underlying asset yaitu: tanah, bangunan, dan proyek yang dimiliki oleh Pemerintah. Selain itu, saat ini Pemerintah juga mengembangkan jenis-jenis Sukuk Negara tematik yang disesuaikan dengan kebutuhan pembiayaan dan juga preferensi investor. Jenis Sukuk Negara tersebut diantaranya adalah: Project Financing
Sukuk dan Green Sukuk. Kedua jenis Sukuk Negara tersebut dikembangkan sesuai dengan arah pembiayaan yang digunakan untuk pembangunan infrastruktur dan preferensi investor yang mendukung terciptanya pembangunan berkelanjutan (green development).

Kebijakan Pemerintah dalam pengembangan instrumen pembiayaan berwawasan lingkungan tersebut sebenarnya sejalan dengan program jangka panjang Pemerintah dan Perserikatan Bangsa-Bangsa (PBB) dalam mewujudkan Sustainable Development Goals (SDGs) atau Tujuan Pembangunan Berkelanjutan.

Tujuan Pembangunan Berkelanjutan tersebut berisi 17 tujuan dan 169 target merupakan rencana aksi global untuk 15 tahun ke depan (berlaku sejak 2016 hingga 2030), guna mengakhiri kemiskinan, mengurangi kesenjangan, dan melindungi lingkungan. SDGs berlaku bagi seluruh negara (universal), sehingga seluruh negara tanpa kecuali memiliki kewajiban moral untuk mencapai Tujuan dan Target SDGs.

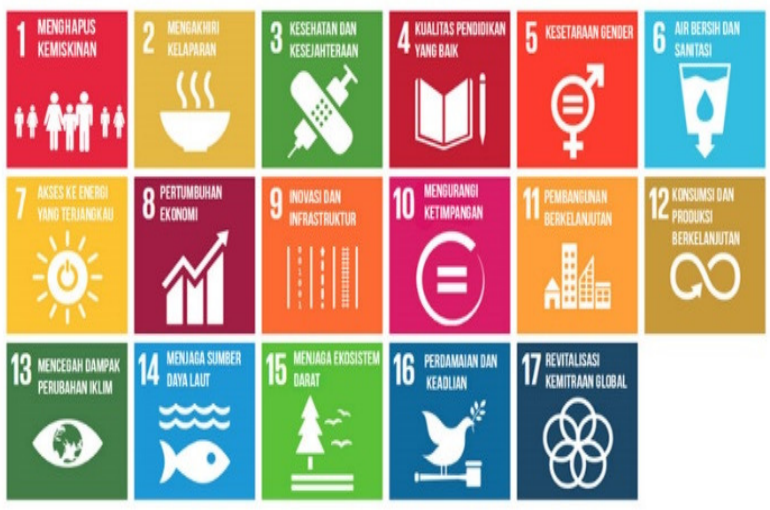

Gambar 1. Tujuan Pembangunan Berkelanjutan

Salah satu tujuan pembangunan yang membutuhkan perhatian lebih adalah Tujuan Pembangunan Butir 14 yaitu konservasi dan pemanfaatan secara berkelanjutan sumber daya laut, samudera, dan maritim untuk pembangunan yang berkelanjutan.

Secara khusus, Indonesia sangat berkepentingan terhadap Tujuan Pembangunan Berkelanjutan Butir 14 tersebut, mengingat Indonesia merupakan negara maritim dengan jumlah pulau terbanyak di dunia (archipelagic state) (Dermawan, 2019). Hampir 75 persen dari total luas wilayah Indonesia merupakan laut dengan luas mencapai 5,8 juta Kilometer persegi yang menjadikan Indonesia sebagai negara dengan wilayah laut terbesar di dunia. Indonesia juga merupakan negara dengan garis pantai terpanjang kedua di dunia yaitu sepanjang 99.093 Kilometer 
(Dermawan, 2017, hal. 1). Berbagai sumber daya maritim tersebut sangat potensial untuk menciptakan kemakmuran bagi seluruh rakyat Indonesia, terutama yang tinggal di daerah pesisir. Ironisnya, tingkat kemiskinan masyarakat pesisir Indonesia relatif masih sangat mengkhawatirkan dengan tingkat Poverty Headcount Index (PHI) mencapai 32,4\% (Dahuri, 2010).

Diketahui bersama bahwa bidang ekonomi kelautan masih merupakan sektor yang relatif tertinggal bila dilihat dari rendahnya produktivitas tingkat pemanfaatan sumber daya, tingkat teknologi yang digunakan, tingkat kemiskinan, tingkat ramah lingkungannya, dan minat investasi skala menengah dan besar relatif kurang, serta besarnya capital yang dibutuhkan walaupun memiliki rate of return yang juga tinggi (Rani \& Cahayasari, 2015, hal. 7).

Sektor kelautan memiliki permasalahan yang kompleks karena keterkaitannya dengan banyak sektor dan juga sensitif terhadap interaksi terutama dengan aspek lingkungan. Terdapat berbagai isu pengelolaan perikanan laut di Indonesia yang berpotensi mengancam kelestarian sumber daya ikan dan lingkungan, keberlanjutan mata pencaharian masyarakat di bidang perikanan, ketahanan pangan, dan pertumbuhan ekonomi yang bersumber dari pemanfaatan sumber daya perikanan(Adrianto (Ed), 2015, hal. 25).

Pada pembukaan Sustainable Development Goals Annual Meeting di Jakarta, 8 Oktober 2019, Jusuf Kalla, sebagai Wakil Presiden pada saat itu, mengakui permasalahan pembiayaan sebagai salah satu faktor belum optimalnya pembangunan di sektor kelautan. Pada sisi lainnya, sebenarnya sangat banyak proyek-proyek yang dapat dikembangkan di sektor kelautan yang dapat mendorong pemanfaatan laut Indonesia secara lebih optimal. Selain itu dengan pemanfaatan laut yang lebih optimal, dapat meningkatkan kesejahteraan nelayan Indonesia (Bayu, 2019, hal. $1)$.

Kebutuhan dana pembangunan yang sangat besar pada sektor kelautan ini menjadi sebuah peluang dalam mengembangkan instrumen pembiayaan. Dalam media massa, Pemerintah telah beberapa kali menyampaikan wacana penerbitan Blue Sukuk atau Sukuk Biru. Hasil penerbitan Sukuk Biru rencananya digunakan untuk pembiayaan pembangunan sektor kelautan. Pemerintah memerlukan dukungan penelitian untuk mendorong implementasi kebijakan tersebut.

Sampai dengan saat ini, Seychelles merupakan negara pertama dan satu-satunya di dunia yang menerbitkan instrumen pembiayaan berbasis lingkungan yang dikhususkan untuk sektor kelautan (Blue Bond) pada bulan Oktober 2018 dengan nilai USD 15 juta (World Bank, 2018). Belum ada negara atau institusi keuangan di dunia yang menerbitkan instrumen pembiayaan berbasis syariah (sukuk) khusus untuk sektor kelautan.

Oleh karena itu, penelitian ini menjadi sangat penting bagi Pemerintah, khususnya Kementerian Keuangan, sebagai bentuk penyusunan kebijakan berbasis riset (Research-based Policy) yang mendukung implementasi penerbitan Blue Sukuk. Penelitian ini diharapkan dapat menjawab kelayakan penerbitan Blue Sukuk sebagai alternatif pembiayaan yang potensial dan strategi yang harus ditempuh oleh Pemerintah untuk menyukseskan implementasi Blue Sukuk.

\section{KERANGKA TEORI DAN PENGEMBANGAN HIPOTESIS}

\subsection{Blue Economy}

Kesadaran akan pentingnya fungsi laut serta kebutuhan untuk melindungi sumber daya yang terkandung di dalamnya semakin meningkat dan mendapat momentum dalam beberapa tahun terakhir. Jumlah negara yang menerapkan kebijakan kelautan (ocean policy) dalam tatanan hukum nasional juga semakin meningkat. Seiring dengan hal tersebut, kondisi ekosistem laut di beberapa bagian dunia mengalami penurunan akibat ulah manusia dan perubahan alam seperti dampak perubahan iklim.

Pada tahun 2010, Gunter Pauli memperkenalkan suatu pendekatan baru yakni Blue Economy melalui bukunya yang berjudul The Blue Economy: 10 years, 100 innovations, and 100 million jobs. Konsep Blue Economy dimaksudkan untuk menantang para pengusaha bahwa Blue Economy Business Model memberikan peluang untuk mengembangkan investasi dan bisnis yang lebih menguntungkan secara ekonomi dan lingkungan, menggunakan sumber daya alam lebih efisien dan tidak merusak lingkungan, sistem produksi lebih efisien dan bersih, menghasilkan produk dan nilai ekonomi lebih besar, meningkatkan penyerapan tenaga kerja, dan memberikan kesempatan untuk memberikan manfaat kepada setiap kontributor secara lebih adil (Pauli (2006) dalam Nurhayati, 2013, hal. 38).

Ekonomi biru kemudian berkembang dan sering dikaitkan dengan pengembangan daerah pesisir. Konsep ekonomi biru sejalan dengan konsep ekonomi hijau yang ramah lingkungan dan difokuskan pada negara-negara berkembang dengan wilayah perairan (laut), yang biasa dikenal dengan Small Island Development States (SIDS). Ekonomi biru dalam hal ini ditujukan untuk mengatasi kelaparan, mengurangi kemiskinan, menciptakan kehidupan laut yang berkelanjutan, mengurangi risiko bencana di daerah pesisir, dan 
mitigasi serta adaptasi perubahan iklim (Rakhmindyarto \& Sinulingga, 2014). Blue Economy merupakan konsep optimalisasi sumber daya perairan yang bertujuan untuk meningkatkan pertumbuhan ekonomi melalui berbagai kegiatan yang inovatif dan kreatif dengan tetap menjamin keberlanjutan usaha dan kelestarian lingkungan. Konsep ini mengedepankan dan menitikberatkan pada efisiensi. Efisiensi mendorong adanya pengembangan investasi dan bisnis perikanan dengan tetap menjaga lingkungan tetap lestari. Inti utama dari Blue Economy ini adalah kegiatan yang pro ekosistem (Ilma, 2017, hal. 3)

Dari uraian tersebut di atas, maka dapat disarikan bahwa esensi konsep Blue Economy adalah:

a. Belajar dari alam: Blue Economy mencontoh cara kerja alam (ekosistem), bekerja sesuai dengan apa yang disediakan alam dengan efisien dan tidak mengurangi tapi justru memperkaya alam.

b. Logika ekosistem: Seperti air mengalir dari gunung membawa nutrien dan energi untuk memenuhi kebutuhan dasar kehidupan seluruh makhluk hidup dan tanaman, limbah dari yang satu menjadi makanan/sumber energi bagi yang lain, sehingga sistem kehidupan dalam ekosistem menjadi seimbang. Hanya dengan gravitasi energi didistribusikan secara efisien dan merata tanpa ekstraksi energi eksternal. Untuk mendukung sistem kehidupan, sinar matahari menjadi energi fotosintesa seluruh kontributor yang membutuhkannya.

c. Inovasi dan Kreativitas: Secara empiris inovasi ekonomi praktis telah dikembangkan dan membuktikan bahwa ekosistem selalu bekerja menuju tingkat efisiensi lebih tinggi untuk mengalirkan nutrien dan energi tanpa meninggalkan limbah untuk mendayagunakan kemampuan seluruh kontributor dan memenuhi kebutuhan dasar bagi semuanya.

Blue Economy pada akhirnya akan menjamin bahwa suatu pembangunan yang dijalankan tidak hanya akan menghasilkan pertumbuhan ekonomi, tetapi juga menjamin terjadinya keberlanjutan secara ekologi dan sosial. Secara umum, Blue Economy dapat dipahami sebagai sebuah model ekonomi untuk mendorong pelaksanaan pembangunan berkelanjutan dengan kerangka pikir seperti cara kerja ekosistem.

Penerapan Blue Economy harus memiliki pemahaman komprehensif terhadap aspek konektivitas antar sektor yang bersama-sama memanfaatkan ekosistem laut dan pesisir. Misalnya pembangunan areal perkotaan yang terletak di daerah pesisir, akan sangat bergantung pada akses terhadap sumberdaya lainnya seperti air dan energi. Demikian halnya dalam aspek perdagangan maritim yang tergantung pada supply barang maritim dan jasa pelabuhan. Hal ini memerlukan pengaturan yang harus dilaksanakan se-efisien mungkin.

Blue Economy sejalan dengan tekad Perserikatan Bangsa-Bangsa dalam mewujudkan Tujuan Pembangunan Berkelanjutan yang ditetapkan oleh negara-negara anggota PBB pada tanggal 25 September 2015. Tentang rangkaian Agenda Pembangunan Berkelanjutan 2030 yang menyertakan 17 Tujuan Pembangunan Berkelanjutan, atau Sustainable Development Goals (SDGs). SDGs disusun berdasarkan Tujuan Pembangunan Milenium, atau Millenium Development Goals (MDGs), yang telah diupayakan dari tahun 2000 sampai 2015, dan akan memandu pencapaian tujuan global yakni pembangunan berkelanjutan hingga tahun 2030 nanti.

Konsep Blue Economy di sektor kelautan dalam rangka pembangunan berkelanjutan di Indonesia memberikan cara kerja yang berkelanjutan (sustainability), cara kerja pada sektor kelautan dilakukan dengan cara back to nature. Pada dasarnya Blue Economy merupakan konsep ekonomi baru yang menjadi harapan atas dua masalah besar yang sedang dialami dunia, yakni permasalahan lingkungan dan krisis energi. (Sitorus, 2018, hal. 13).

Forum kerjasama ekonomi terbuka Asia Pasifik yaitu Asia-Pacific Economic Cooperation (APEC) dibentuk sebagai upaya untuk memajukan segala aspek kegiatan ekonomi di Asia-Pasifik pada bulan November 1989 di Canberra, Australia. Dengan anggota sebanyak 21 negara yakni, Australia, Brunei Darussalam, Kanada, Chili, China, Indonesia, Jepang, Korea Selatan, Malaysia, Mexico, New Zealand, Papua Nugini, Peru, Filipina, Rusia, Singapura, China-Taipei, Thailand, Amerika Serikat, dan Vietnam (Rani \& Cahayasari, 2015, hal. 2).

APEC mendefinisikan Blue Economy sebagai model ekonomi yang mendorong pelaksanaan pembangunan yang berkelanjutan (sustainable). Model ekonomi yang mengembangkan industrialisasi kelautan dan perikanan yang menekankan pada pertumbuhan, penciptaan lapangan kerja, dan mendorong inovasi teknologi ramah lingkungan. Pembangunan kelautan yang kurang optimal dan cenderung tidak berkelanjutan (unsustainable) disebabkan oleh pola pembangunan yang kurang berbasis ilmu pengetahuan dan teknologi (IPTEK), tidak menerapkan pendekatan supply-chain system secara terpadu, kurang inklusif, dan tidak ramah lingkungan.

Penerapan model Blue Economy di Indonesia dimulai sejak Presiden Susilo Bambang Yudhoyono menyampaikan pidato pada Konferensi Tingkat 
Tinggi (KTT) Rio+20 di Riocentro, Rio de Janeiro, Brasil yang dilaksanakan selama sembilan hari mulai 13-22 Juni 2012. KTT Pembangunan Berkelanjutan atau KTT Rio+20 diikuti oleh 191 negara yang dihadiri 105 kepala negara dan kepala pemerintahan dan 487 menteri. Alasan Indonesia untuk menerapkan model Blue Economy dilandasi oleh kenyataan kondisi geografis Indonesia adalah negara kepulauan yang memiliki garis pantai terpanjang kedua di dunia (setelah Kanada), sehingga perlu dipikirkan bagaimana caranya untuk melestarikan sumber daya laut karena pelestarian sumber daya laut ini akan berdampak pada cadangan sumber pangan masyarakat yang bisa diandalkan.

Berkaitan dengan penerapan konsepsi Blue Economy di ekosistem laut, sekurang-kurangnya ada 3 hal utama yang menjadi dasar pendekatannya, yakni: kondisi kesehatan ekosistem (Healthy Ocean), aktivitas ekonomi yang berpusat pada kesejahteraan masyarakat (Peoplecentered activities), dan adanya tata-kelola sumberdaya yang baik (Ocean Governance).

\subsection{Sukuk Negara atau Surat Berharga Syariah Nasional (SBSN)}

Dalam Ekonomi Islam, Sukuk pada dasarnya bukanlah sesuatu yang baru. Sukuk telah lama dipergunakan sebagai instrumen keuangan dalam perdagangan domestik maupun internasional oleh para pedagang muslim sejak awal perkembangan Islam (abad keenam masehi). Istilah Sukuk kemudian menjadi populer pada abad 21 setelah banyak digunakan oleh pemerintah maupun korporasi dalam memobilisasi dana guna pembiayaan suatu proyek tertentu dalam skala interasional. (Hariyanto, 2017a, hal. 3).

Secara bahasa Sukuk dapat diartikan sebagai dokumen atau sertifikat. Istilah Sukuk sendiri berasal dari bahasa arab dengan kata dasar صك yang berarti dokumen atau sertifikat, serta bentuk jamaknya adalah صكوك (sukuk). Istilah Sukuk dapat ditemukan dalam berbagai literatur Islam klasik, yaitu pada awal abad permulaan Islam (awal abad hijriah/abad keenam masehi) dengan berbagai variasi penyebutan nama, seperti sakk, sukuk atau sukaik. Istilah tersebut memiliki arti sebagai suatu sertifikat atau dokumen. Dalam kitab Al-Muawatta' karya Imam Malik disebutkan bahwa Sukuk telah digunakan sejak abad pertama Hijriah pada masa pemerintahan halifah Al-Marwan ibn Al-Hakam, yaitu zaman dinasti Bani Umayyah. (Direktorat Pembiayaan Syariah DJPPR, 2015, hal. 19)

Sukuk juga sudah dijelaskan dalam Peraturan Badan Pengawas Pasar Modal Lembaga Keuangan No. IX.A.13 mengenai efek syariah, Sukuk didefinisikan sebagai efek syariah berupa sertifikat atau bukti kepemilikan yang bernilai sama dan mewakili bagian yang tidak tertentu yang meliputi: aset berwujud, nilai manfaat atas aset, jasa, aset proyek tertentu, kegiatan investasi yang telah ditentukan.

Indonesia sebagai negara penerbit sukuk yang terpercaya sudah saatnya menggunakan instrumen ini untuk mempromosikan peran Indonesia dalam mendukung terciptanya bumi yang lebih nyaman. Sukuk sebagai instrumen keuangan yang banyak memiliki kemiripan dengan obligasi (bond) dapat digunakan untuk mendukung program-program dalam rangka mengurangi pemanasan global dan dampaknya (Hariyanto, 2017b, hal. 73).

Undang-undang Nomor 19 Tahun 2008 mendefinisikan Sukuk Negara merupakan surat berharga negara yang diterbitkan berdasarkan prinsip syariah dalam mata uang rupiah maupun valuta asing. Penerbitan Sukuk Negara bertujuan untuk membiayai defisit APBN dan juga pembiayaan kegiatan atau proyek prioritas negara. (Hariyanto, 2017c, hal. 9)

Sukuk Negara menunjukkan sebuah terobosan yang penting dan membuka banyak peluang baru pada ranah keuangan dan perbankan syariah. Sukuk telah menunjukkan perannya, bahwa instrumen Sukuk mempunyai andil dalam pembangunan nasional dengan membantu Pemerintah untuk memenuhi kas negara ketika pajak tidak terpenuhi (Adam \& Thomas, 2004, hal. 18).

Penerbitan Sukuk Negara dalam rangka pembiayaan APBN dimaksudkan untuk mengamankan kebutuhan pembiayaan APBN dengan biaya minimal pada tingkat risiko terkendali, sehinga menjaga kesinambungan fiskal. Sedangkan yang dimaksud pembiayaan proyek adalah dalam rangka membiayai pembangunan proyek pemerintah yang dialokasikan dalam APBN, seperti proyek infrastruktur dalam sektor energi, telekomunikasi, perhubungan, pertanian, industri manufaktur, dan perumahan rakyat (Direktorat Pembiayaan Syariah, 2011, hal. 173).

\subsection{Project Financing Sukuk}

Sejak tahun 2011, Pemerintah mulai fokus pada penerbitan Sukuk Negara untuk pembiayaan proyek. Penerbitan Sukuk Negara dalam rangka pembiayaan proyek dilakukan berdasarkan ketentuan Undang-Undang Nomor 19 Tahun 2008 tentang Surat Berharga Syariah Negara yang memberikan amanat bahwa pembiayaan proyek dalam rangka pelaksanaan APBN dapat bersumber dari penerbitan Sukuk Negara. Penerbitan Sukuk Negara untuk pembiayaan proyek APBN merupakan salah satu tahapan yang diharapkan dapat menjadi pendorong tercapainya tujun pembangunan nasional. 
Seperti yang telah dijelaskan sebelumnya, Sukuk Negara diperuntukkan untuk membiayai defisit APBN dan kegiatan atau proyek prioritas negara (Project Financing). Project Financing Sukuk merupakan mekanisme pembiayaan melalui penerbitan Sukuk Negara khusus untuk proyek infrastruktur dan proyek strategis lainnya. Pembiayaan proyek melalui Sukuk negara mengacu pada Peraturan Pemerintah (PP) Nomor 56 Tahun 2011. Dalam PP tersebut dinyatakan bahwa proyek yang dibiayai dengan Sukuk negara dilakukan dalam rangka:

a. Pembangunan infrastruktur;

b. Peningkatan pelayanan publik;

c. Pemberdayaan industri dalam negeri; dan

d. Program Pemerintah lainnya yang bersifat strategis.

Proyek yang dibiayai pun harus merupakan proyek prioritas. Cakupan proyek melingkupi pembangunan infrastruktur seperti sektor energi, telekomunikasi, perhubungan, pertanian, industri manufaktur, dan perumahan rakyat; penyediaan pelayanan umum; pemberdayaan industri dalam negeri; pembangunan lain sesuai dengan kebijakan strategis Pemerintah. Sedangkan persyaratan proyek adalah:

a. Merupakan proyek Pemerintah pusat;

b. Sesuai dengan prioritas;

c. Memenuhi kriteria kesiapan dan kelayakan untuk dilaksanakan dari BAPPENAS;

d. Telah memperoleh persetujuan dari DPR;

e. Telah mendapatkan alokasi dalam APBN;

f. Memenuhi kriteria dan tidak bertentangan dengan prinsip syariah;

g. Tidak akan dipindahtangankan/dihapuskan selama menjadi aset Sukuk Negara.

Selain itu, proyek yang dibiayai oleh Sukuk Negara juga harus memenuhi kriteria syariah. Berikut adalah penjelasannya dalam ketetapan DSN-MUI No. 01/DSN-MUI/III/2012:

1. Proyek memiliki kejelasan perencanaan, pelaksanaan dan penyelesaian, sekurangnya meliputi aspek: (a) Rencana pemanfaatan, (b) Rencana pembangunan proyek dari segi manfaat dan mudarat;

2. Pemanfaatan proyek bukan untuk tujuan yang berkaitan dengan: (a) Penyelenggaraan dan/atau adanya kontribusi terhadap jasa keuangan konvensional (ribawi), Penyelenggaraan dan/atau adanya kontribusi terhadap kegiatan yang mngandung unsur perjudian (maysir), (c) Penyelenggaraan dan/atau adanya kontribusi terhadap produksi, distribusi, perdagangan, dan/atau penyediaan barang/jasa yang dilarang (haram), (d) Penyelenggaraan dan/atau adanya kontribusi terhadap kegiatan yang bersifat merusak/berbahaya (mudarat) terhadap akhlak moral maupun lingkungan.

Pembiayaan proyek negara dengan Sukuk Negara selalu mengalami peningkatan setiap tahunnya. Proyek yang dibiayai meliputi infrastruktur transportasi seperti jembatan, jalan, dan rel kereta api. Selain itu Sukuk Negara juga membiayai proyek infrastruktur pendidikan seperti gedung perguruan tinggi, infrastruktur Kementerian Agama seperti Kantor Urusan Agama (KUA), dan juga infrastruktur Haji seperti Asrama Haji, serta infrastruktur lainnya seperti jalan dan jembatan. (Direktorat Pembiayaan Syariah DJPPR, 2015, hal. 169).

Prosedur pembiayaan dirangkum menjadi 5 proses, yaitu: (1) Kementerian/Lembaga merencanakan proyek, (2) Kementerian/Lembaga mengusulkan proyek kepada BAPPENAS, (3) BAPPENAS menyampaikan Daftar Prioritas proyek Kementerian Keuangan, (4) Selanjutnya, Kementerian Keuangan c.q. DJPPR akan mempersiapkan pembiayaan proyek melalui penerbitan Sukuk Negara, (5) Kementerian/Lembaga melaksanakan pembangunan proyek yang dibiayai dengan Sukuk Negara.

Kementerian/Lembaga bersangkutan melakukan pengawasan, pemantauan, dan melakukan pengelolaan atas obyek pembiayaan. Selain hal tersebut, Kementerian/Lembaga juga harus menyampaikan laporan mengenai perkembangan pelaksanaan proyek kepada Menteri dan Menteri Perencanaan sesuai dengan ketentuan PP Nomor 56 tahun 2011. Penyampaian laporan mencakup perkembangan pencapaian pelaksanaan fisik proyek serta perkembangan realisasi penyerapan anggaran.

\subsection{Kebijakan Fiskal}

Pemerintah menetapkan berbagai kebijakan dalam mengelola perekonomian negara, salah satunya adalah kebijakan fiskal. Kebijakan fiskal merupakan kewenangan Pemerintah dalam mengatur pendapatan dan belanja negara yang bertujuan untuk mempengaruhi jalannya perekonomian agar menjadi lebih baik (Hariyanto, 2017a, hal.22).

Dalam sepuluh tahun terakhir, Pemerintah menerapkan kebijakan anggaran ekspansif. Kebijakan ini adalah strategi Pemerintah yang bertujuan untuk mendorong laju pertumbuhan ekonomi. Dalam kebijakan ekspansif, Pemerintah memperbesar pengeluaran dengan meningkatkan anggaran belanja pembangunan infrastruktur dan 
proyek-proyek Pemerintah lainnya. Kegiatan pembangunan tersebut diharapkan dapat mendorong masyarakat untuk menyediakan barang dan jasa yang lebih banyak, terciptanya lapangan kerja, serta meningkatkan konsumsi. Siklus tersebut selanjutnya diharapkan dapat menciptakan pertumbuhan ekonomi yang lebih tinggi dan kesejahteraan masyarakat (Hariyanto, 2017b, hal. 7).

Dalam pembiayaan defisit APBN, Pemerintah juga telah memiliki berbagai instrumen sumber pembiayaan anggaran. Diantara instrumen tersebut adalah pinjaman langsung dan penerbitan Surat Utang Negara. Surat Utang Negara yang diterbitkan meliputi dua, Surat Berharga Negara dan Surat Berharga Syariah Negara (SBSN atau Sukuk Negara).

\subsection{Penelitian Terdahulu}

Penelitian pertama dari Moolna \& Thompson (2018) berjudul: "The Blue Economy approach for sustainability in Seychelles \& East Africa". Hasil penelitian tersebut menyatakan bahwa pendekatan Ekonomi Biru terhadap pembangunan ekonomi berkelanjutan kelautan dan daerah pesisir di Seychelles dan di seluruh Afrika Timur menjanjikan potensi besar. Namun peneliti juga berpendapat bahwa kebijakan Ekonomi Biru sebagai "solusi" pembangunan berkelanjutan merupakan konsensus kebijakan politik tingkat tinggi. Hal tersebut sangat membatasi evaluasi kritis terhadap peluang dan risiko di tataran implementasi dan cenderung menghindari perdebatan tentang berbagai kompromi yang dibutuhkan.

Penelitian kedua dari Sitorus (2018) yang berjudul Analisis Konsep Blue Economy Pada Sektor Kelautan Di Indonesia Berdasarkan UndangUndang Nomor 32 Tahun 2014 Tentang Kelautan. Dalam penelitian ini konsep Blue Economy di sektor kelautan dalam rangka pembangunan berkelanjutan di Indonesia memberikan cara kerja yang berkelanjutan (sustainability), cara kerja pada sektor kelautan dilakukan dengan cara back to nature. Pada dasarnya Blue Economy merupakan konsep ekonomi baru yang menjadi harapan atas dua masalah besar yang sedang dialami dunia, yakni permasalahan lingkungan dan krisis energi. Di tengah kerumitan inilah, konsep Blue Economy hadir sebagai solusi yang tepat dan berkelanjutan (exact and sustainable solution). Indonesia lebih berkonsentrasi pada industri manufaktur dan jasa yang banyak menggunakan bahan baku dari luar negeri. Sementara itu, industri yang berbasis sumber daya alam (resources-based industries) seperti sektor kelautan dan perikanan selama ini belum mendapat perhatian yang serius dari pemerintah dan kalangan pengusaha. Solusi dari kendala di atas yaitu dengan memperbaiki kebijakan yang mengaturnya serta berkaitan dengan aspek hukumnya dan kelembagaannya. Meningkatkan dan menguatkan sumber daya manusia di bidang kelautan.

Penelitian ketiga oleh Anggraini (2018) yang berjudul Peran Green Sukuk Dalam Memperkokoh Posisi Indonesia Di Pasar Keuangan Syariah Global. Penelitian ini menyampaikan bahwa Pemerintah Indonesia terus berkomitmen untuk mendorong pengembangan Sukuk Negara sebagai bagian dari kreatif dan innovative financing dalam pembiayaan APBN. Dalam hal ini pembahasan pada Green Sukuk. Selain itu, berbagai upaya juga dilakukan untuk mendukung pendalaman pasar dan memperluas basis investor domestik, serta meningkatkan likuiditas Sukuk Negara di pasar sekunder, antara lain melalui inovasi instrumen, penyempurnaan infrastruktur kelembagaan dan pasar SBSN, termasuk pengembangan jalur distribusinya.

\section{METODOLOGI PENELITIAN}

\subsection{Tempat dan Waktu Penelitian}

Penelitian ini dilakukan di beberapa lokasi sebagai berikut:

1. Direktorat Pembiayaan Syariah DJPPR, Kementerian Keuangan di Jakarta;

2. Kantor Pusat Kementerian Kelautan dan Perikanan di Jakarta;

3. Departemen Ilmu dan Teknologi Kelautan, FKIP Universitas IPB di Bogor; dan

4. Kampung nelayan Desa Karangsong, Kabupaten Indramayu, dan Desa Cangol Kabupaten Cirebon Jawa Barat.

Penelitian ini dilaksanakan pada bulan Agustus s.d. September 2019.

\subsection{Jenis Penelitian}

Penelitian ini menggunakan dua metode yaitu Regulatory Impact Analysis (RIA) dan Strenght, Weakness, Opprtunity, and Threat Analysis (SWOT). Metode RIA digunakan untuk mengukur nilai biaya dan manfaat dari rencana penerbitan Blue Sukuk. Penggunaan metode ini diharapkan dapat mengkuantifikasi nilai biaya dan manfaat sehingga mempermudah dalam memberikan rekomendasi kebijakan.

Analisis SWOT digunakan untuk menganalisis faktor-faktor internal dan eksternal yang dapat menjadi pendukung sekaligus penghambat dari rencana penerbitan Blue Sukuk. Penggunaan metode ini dengan harapan mendapatkan strategi yang tepat dalam menggunakan kekuatan dan peluang yang ada untuk mengatasi segala ancaman dan mengurangi kelemahan yang ada sehingga implementasi penerbitan Blue Sukuk dapat berlangsung dengan baik. 


\subsection{Sumber dan Metode Pengumpulan Data}

Penelitian ini menggunakan data primer dan sekunder. Data primer didapatkan dari pengisian kuesioner oleh pakar, regulator, dan praktisi yang berjumlah lima orang. Sedangkan data sekunder diperoleh dari berbagai literatur dan publikasi data oleh instansi terkait. Data primer diperoleh melalui: In-depth Interview, yaitu wawancara yang dilakukan secara mendalam untuk menjaring informasi yang detail mengenai objek permasalahan yang dibahas dalam penelitian ini. Dari hasil wawancara, penulis memperoleh data mengenai faktor-faktor yang memengaruhi dan berhubungan implementasi Blue Sukuk untuk pembiayaan pembangunan sektor maritim di Indonesia.

\subsection{Gambaran Umum Regulatory Impact Analysis (RIA)}

Regulatory Impact Analysis (RIA) merupakan salah satu instrumen yang dapat membantu pemerintah untuk menilai dampak regulasi (OECD,2008, hal. 14). RIA merupakan suatu proses yang secara sistematik mengidentifikasi dan menilai dampak yang diinginkan dari suatu pengajuan undang-undang dengan metode analisia yang konsisten seperti analisis biaya-manfaat. Pelaksanaan RIA mendukung proses pembuatan kebijakan dengan ikut serta data empirik berharga bagi keputusan kebijakan, dan melalui pembangunan kerangka keputusan rasional untuk mengkaji potensi pilihan implikasi kebijakan peraturan. Ini merupakan faktor penting dalam menanggapi dampak terhadap ekonomi modern pasar internasional yang terbuka dan kendala anggaran, dan konsekuensi dari tuntutan kebijakan yang bersaing. Karakteristik khusus dari RIA adalah pertimbangan atas potensi dampak ekonomi proposal peraturan. RIA merupakan alat kebijakan penting untuk mengetahui kualitas peraturan. Tujuan utamadari RIA adalah untuk membantu pemerintah untuk membuat kebijakan mereka lebih hemat.

\subsubsection{Penjelasan 10 (Sepuluh) Pertanyaan RIA}

RIA memiliki 10 standar pertanyaan yang merupakan standar baku yang ditetapkan oleh OECD untuk merumuskan dan melaksanakan peraturan yang lebih baik. Seperti halnya standar dalam ISO 9001 yang digunakan untuk menetapkan standar kualitas mutu, standar RIA tersebut berfokus untuk memperbaiki proses pembuatan peraturan dalam mencapai tujuan peningkatan kualitas peraturan. Perlu digarisbawahi bahwa standar tersebut bukan untuk meningkatkan proses manajemen tetapi diharapkan sebagai sebuah instrumen kebijakan dapat mencapai tingkat kualitas peraturan yang mampu mengakomodasi semua pemangku kepentingan.
Adapun penjelasan rinci dari daftar pertanyaan penyusunan RIA tersebut yaitu:

1) Apakah masalahnya dengan benar telah didefinisikan? Masalah yang harus dipecahkan harus tepat dinyatakan, memberikan bukti dari sifat dan besarnya, dan menjelaskan mengapa hal tersebut muncul (mengidentifikasi entitas insentif yang terkena).

2) Apakah tindakan pemerintah sudah tepat? Intervensi pemerintah harus didasarkan pada bukti eksplisit bahwa tindakan pemerintah dibenarkan, mengingat sifat dari masalah, kemungkinan manfaat dan biaya tindakan (berdasarkan penilaian yang realistis efektivitas pemerintah), dan mekanisme alternatif untuk mengatasi masalah.

3) Apakah regulasi yang ada merupakan yang terbaik untuk langkah pemerintah? Regulator harus melakukan, di awal proses regulasi, sebuah informasi perbandingan berbagai peraturan dan non-peraturan instrumen kebijakan, mengingat masalah-masalah yang relevan seperti biaya, manfaat, efek distribusi dan persyaratan administrasi.

4) Apakah ada dasar hukumnya untuk sebuah peraturan? Proses peraturan harus terstruktur sehingga semua keputusan peraturan ketat menghormati "rule of law"; itu adalah, tanggung jawab harus jelas untuk memastikan bahwa semua peraturan yang diperkenankan oleh peraturan tingkat yang lebih tinggi dan konsisten dengan kewajiban perjanjian internasional, dan sesuai dengan prinsip-prinsip hukum yang relevan seperti kepastian, proporsionalitas dan persyaratan prosedural yang berlaku.

5) Berapa tingkatan birokrasi pemerintah yang dilibatkan untuk koordinasi regulasi ini? Regulator harus memilih tingkat yang paling tepat dari pemerintah untuk mengambil tindakan, atau jika ada beberapa tingkatan yang terlibat, harus merancang sistem yang efektif koordinasi antara tingkat pemerintahan.

6) Apakah regulasi yang ada bermanfaat, dibanding biayanya? Regulator harus memperkirakan total biaya dan manfaat yang diharapkan dari setiap peraturan usulan dan alternatif, dan harus membuat perkiraan tersedia dalam format yang dapat diakses para pengambil keputusan. Biaya tindakan pemerintah harus dapat dibenarkan oleh manfaat sebelum tindakan diambil.

7) Apakah distribusi akan dampaknya transparan di masyarakat? Sejauh distributif dan nilai-nilai ekuitas dipengaruhi oleh 
intervensi pemerintah, regulator harus membuat transparan peraturan distribusi biaya dan manfaat di kelompok-kelompok sosial.

8) Apakah peraturan tersebut jelas, konsisten, dipahami dan diakses oleh pengguna? Regulator harus menilai apakah peraturan akan mungkin dipahami oleh pengguna, dan untuk itu harus mengambil langkah-langkah untuk memastikan bahwa struktur teks dan aturan sejelas mungkin.

9) Apakah semua pihak yang berkepentingan memiliki kesempatan yang sama untuk menyampaikan pandangan mereka? Peraturan harus dikembangkan secara terbuka dan transparan, dengan prosedur yang tepat yang efektif dan tepat waktu masukan dari pihak-pihak yang tertarik seperti bisnis yang terkena dampak dan serikat buruh, kelompok-kelompok kepentingan lainnya, atau tingkat pemerintahan lainnya.

10) Bagaimana kepatuhan akan regulasi itu dapat dicapai? Regulator harus menilai insentif dan lembaga-lembaga melalui peraturan yang akan berlaku, dan harus merancang strategi pelaksanaan tanggap yang membuat penggunaan terbaik dari mereka.

\subsubsection{Analisis Biaya-Manfaat dalam proses RIA}

Analisa Biaya-Manfaat merupakan “jantung” RIA (Regulatory Impact Analysis). Informasi dan isu yang akan dianalisa sedapat mungkin disajikan atau dikonversi ke dalam bentuk kuantitatif. Upaya untuk mengkuantifikasi isu dan informasi dengan menggunakan tolok ukur yang telah dirumuskan tidak mudah, sehingga perlu mengembangkan permasalahan maupun tujuan yang telah diidentifikasi. Oleh sebab itu, klarifikasi kedua hal tersebut merupakan bagian RIA yang sangat penting.

Langkah-langkah praktis berikut ini sering dapat membantu untuk memulai Analisis BiayaManfaat, yaitu:

1) Membuat sebanyak mungkin daftar berbagai jenis manfaat yang diperoleh dari diberlakukannya suatu peraturan;

2) Membuat sebanyak mungkin daftar berbagai jenis biaya yang dikeluarkan sehubungan dengan diterbitkannya/diberlakukannya suatu peraturan;

3) Melakukan konsultasi dengan tenaga ahli, stakeholders, dan masyarakat untuk menyempurnakan daftar manfaat dan biaya tersebut;
4) Menyiapkan tabel tentang manfaat dan biaya yang disajikan per tahun. Membagi tabel dalam kelompok sesuai dengan yang terkena dampak manfaat maupun biaya, berdasarkan "Kelompok Kunci" yang akan mewakili praktisi, akademisi, maupun pemerintah.

Langkah pertama yang dilakukan dalam mengevaluasi efisiensi suatu kebijakan yaitu menentukan komponen manfaat dan komponen biaya yang ditimbulkan dari kebijakan tersebut. Secara sederhana, manfaat adalah hal-hal positif atau menguntungkan suatu pihak. Menurut Choliq (1999, hal. 21), umumnya manfaat dibagi menjadi dua kelompok dasar yaitu manfaat yang berwujud (tangible benefit) dan manfaat yang tidak berwujud (intangible benefit). Manfaat yang berwujud (tangible benefit) cenderung terlihat jelas dalam mengevaluasi atau dengan kata lain diartikan keuntungan yang dapat diukur secara kuantitatif dalam bentuk suatu nilai uang. Manfaat yang tidak berwujud (intangible benefit) sulit untuk diukur, dengan kata lain keuntungan yang sulit atau tidak mungkin diukur dalam suatu nilai uang.

Setelah mengidentifikasi komponen manfaat, selanjutnya yaitu menentukan biaya. Biaya merupakan hal-hal negatif atau merugikan suatu pihak apabila suatu pilihan diambil. Menurut Hariadi (2002, hal. 43), biaya merupakan nilai tukar yang dikeluarkan atau pengorbanan sumber daya yang dikeluarkan untuk mencapai manfaat pengorbanan dapat berupa uang atau materi lainnya yang dapat diukur dengan uang.

Tabel 2. Tahapan dalam menganalisis komponen manfaat dan komponen biaya

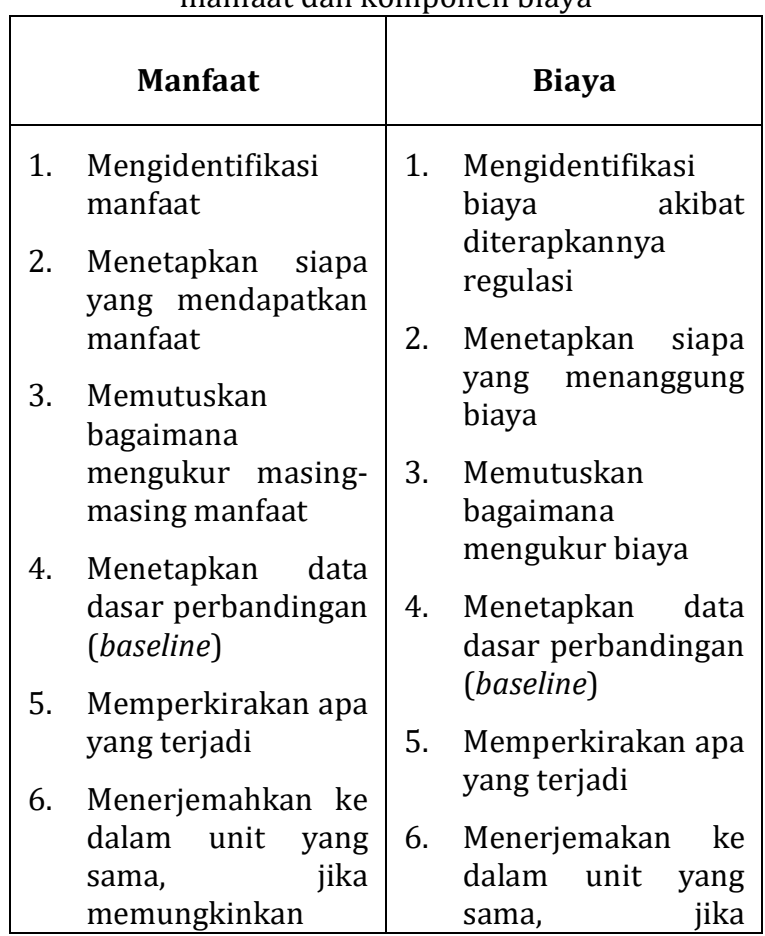




\begin{tabular}{|c|c|c|}
\hline Mer & asil & memungkinkan \\
\hline analisis & & $\begin{array}{l}\text { 7. Meringkas hasil } \\
\text { analisis }\end{array}$ \\
\hline
\end{tabular}

Sumber: DPR (2008)

Setelah melakukan identifikasi atas semua manfaat dan biaya, tahapan selanjutnya yaitu mengukur semua manfaat dan biaya dalam nilai rupiah untuk kemudian dilakukan analisis atas nilai manfaat dan biaya tersebut. Terdapat beberapa metode yang biasa digunakan dalam melakukan Analisis Biaya-Manfaat, di antaranya yaitu dengan metode Net Present Value (NPV), Internal Rate of Return (IRR), dan Benefit-Cost Ratio (BCR). Dalam penelitian ini, metode yang akan digunakan yaitu pendekatan Benefit-Cost Ratio (BCR).

Metode Benefit-Cost Ratio (BCR) adalah suatu cara evaluasi atas suatu proyek dengan membandingkan nilai sekarang dari seluruh hasil yang diperoleh atas proyek tersebut dengan nilai sekarang dari seluruh biaya atas proyek tersebut (Mangkoesoebroto, 2018, hal. 141).

$\mathrm{BCR}=\Sigma$ manfaat

$$
\sum \text { biaya }
$$

- $\quad$ BCR > 1, maka proyek dikatakan layak dikerjakan

- $\quad$ BCR $=1$, maka manfaat yang ditimbulkan proyek sama dengan biaya yang diperlukan secara ekonomi, maka proyek layak untuk dilaksanakan

- BCR < 1 proyek tersebut secara ekonomi tidak layak untuk dibangun

Evaluasi kebijakan melalui Analisis BiayaManfaat memiliki kelebihan dan kekurangan. Menurut Mangkoesoebroto (2018, hal. 142), keuntungan dari penggunaan Analisis BiayaManfaat dalam penentuan program pemerintah adalah terjaminnya penggunaan sumber-sumber ekonomi secara efisien, sebab program-program pemerintah dievaluasi dengan memperhitungkan keadaan perekonomian sehingga dapat meningkatkan penggunaan faktor-faktor produksi. Kelemahan Analisis Biaya-Manfaat yang terbesar untuk tujuan evaluasi proyek-proyek pemerintah adalah karena analisis ini membutuhkan penghitungan manfaat secara kuantitatif, sedangkan banyak proyek-proyek pemerintah yang tidak dapat diukur manfaatnya secara kuantitatif. Kelemahan lain dari Analisis BiayaManfaat adalah karena semua penghitungan (manfaat dan biaya) dilakukan secara kuantitatif, maka analisis ini tidak memiliki fleksibilitas.

\subsection{Analisis SWOT}

3.5.1. Definisi dan Tujuan Analisis SWOT

Kotler \& Keller (2009, hal. 89) menyebutkan bahwa evaluasi keseluruhan dari kekuatan, kelemahan, peluang, dan ancaman disebut juga dengan istilah Analisis SWOT (Strength, Weakness, Opportunity, Threat). Rincian pengertiannya sebagaimana tersebut di bawah ini:

1. Strength (Kekuatan)

Yaitu merupakan kekuatan yang dimiliki oleh perusahaan dibandingkan dengan perusahaan lainnya.

2. Weakness (Kelemahan)

Yaitu masalah-masalah yang dihadapi oleh perusahaan dibandingkan dengan perusahaan lain, sehingga ini menjadi nilai minus/kelemahan bagi perusahaan.

3. Opportunity (Peluang)

Merupakan suatu kesempatan di mana perusahaan dapat melakukan operasi dalam menghadapinya untuk menjadikan kesempatan itu menjadi sebuah keuntungan.

4. Threat (Ancaman)

Yaitu merupakan suatu bahaya yang biasanya dikarenakan perkembangan yang kurang menguntungkan, dimana akan memberikan dampak seperti pengurangan laba dan penjualan jika tidak dilakukan tindakan untuk bertahan.

Menurut Rangkuti (2016, hal. 18), Analisis SWOT adalah identifikasi berbagai faktor secara sistematis untuk merumuskan strategi perusahaan. Analisis SWOT membandingkan antara faktor eksternal peluang (opportunities) dan ancaman (threats) dengan faktor internal kekuatan (strengths) dan kelemahan (weakness).

Manfaat dari Analisis SWOT adalah meningkatkan pengetahuan dan pemahaman organisasi sehingga mampu menganalisis apa yang menjadi kekuatan, kelemahan, peluang, dan ancaman dalam organisasi untuk mendapatkan strategi yang tepat dengan menggunakan kekuatan dan peluang yang ada untuk mengatasi segala ancaman dan mengurangi kelemahan yang ada sehingga organisasi dapat bertahan dan mampu untuk berkembang.

Pengenalan akan kekuatan yang dimiliki akan membantu perusahaan untuk tetap menaruh perhatian dan melihat peluang-peluang baru. Sedangkan penilaian yang jujur terhadap kelemahan-kelemahan yang ada akan memberikan bobot realisme pada rencana-rencana yang akan dibuat perusahaan. Jadi fungsi analisis SWOT adalah menganalisis mengenai kekuatan dan kelemahan yang dimiliki perusahaan, serta analisa mengenai peluang dan ancaman yang akan dihadapi perusahaan uang dilakukan melalui 
telaah terhdap kondisi ekternal perusahaan (Rangkuti, 2016, hal. 11).

Tujuan analisis SWOT adalah mengidentifikasi strategi perusahaan secara keseluruhan. Hampir setiap perusahaan maupun pengamat bisnis dalam pendekatannya banyak menggunakan Analisis SWOT. Kecenderungan ini tampaknya akan terus semakin meningkat, terutama dalam era perdagangan bebas di abad 21, yang mana satu sama yang lain saling berhubungan dan bergantung. Penggunaan Analisis SWOT ini sebenarnya telah muncul sejak ribuan tahun lau dari bentuknya yang paling sederhana, yaitu dalam rangka menyusun strategi unuk mengalahkan musuh dalam pertempuran (Rangkuti, 2016, hal. 19).

\subsubsection{Rancangan SWOT}

Faktor internal dalam Analisis SWOT diperoleh dari data lingkungan perusahaan, seperti laporan keuangan, kegiatan operasional, kegiatan pemasaran, dan data staf atau karyawan. Sedangkan faktor eksternal diperoleh dari lingkungan di luar perusahaan, seperti analisis pasar, kompetitor (pesaing), komunitas, pemasok, pemerintah, dan analisis kelompok (kepentingan tertentu). Perencanaan usaha yang baik dengan metode Analisis SWOT dirangkum dalam matriks SWOT yang dikembangkan oleh Kearns dalam Rangkuti (2006, hal. 19).

Tabel 5.Matriks Strategi SWOT

\begin{tabular}{|c|c|c|}
\hline $\begin{array}{ll} & \text { IFAS } \\
\text { EFAS } & \end{array}$ & $\begin{array}{l}\text { Kekuatan } \\
\text { (Strength) }\end{array}$ & $\begin{array}{l}\text { Kelemahan } \\
\text { (Weakness) }\end{array}$ \\
\hline $\begin{array}{c}\text { Peuang } \\
\text { (Opportunity) }\end{array}$ & $\begin{array}{c}\text { STRATEGI SO } \\
\text { Ciptakan strategi } \\
\text { yang } \\
\text { menggunakan } \\
\text { kekuatan untuk } \\
\text { memanfaatkan } \\
\text { peluang }\end{array}$ & $\begin{array}{l}\text { STRATEGI WO } \\
\text { Ciptakan } \\
\text { strategi yang } \\
\text { menimalkan } \\
\text { kelemahan } \\
\text { untuk } \\
\text { memanfaatkan } \\
\text { peluang }\end{array}$ \\
\hline $\begin{array}{l}\text { Ancaman } \\
\text { (Threats) }\end{array}$ & $\begin{array}{c}\text { STRATEGI ST } \\
\text { Ciptakan srategi } \\
\text { yang } \\
\text { menggunakan } \\
\text { kekuatan untuk } \\
\text { mengatasi } \\
\text { ancaman }\end{array}$ & $\begin{array}{l}\text { STRATEGI WT } \\
\text { Ciptakan } \\
\text { strategi yang } \\
\text { meminimalkan } \\
\text { kelemahan dan } \\
\text { menghindari } \\
\text { ancaman }\end{array}$ \\
\hline
\end{tabular}

EFAS merupakan External Strategic Factors Analysis Summary yaitu faktor-faktor strategis yang berasal dari luar perusahaan. Sedangkan IFAS adalah Internal strategic Factors Analysis Summary yaitu faktor-faktor strategis yang berasal dari dalam perusahaan. Keduanya kemudian dibandingkan yang dapat menghasilkan aternatif strategi SO, ST, WO, dan WT.



Sumber: Rangkuti (2009) dari buku Analisis SWOT Teknik Membedah Kasus Bisnis. PT. Gramedia Pustaka Utama

Keterangan masing-masing kuadran diagram analisis SWOT adalah:

1. Kuadran I (Strategi So/Agresif)

Ini merupakan situasi yang sangat menguntungkan. Perusahaan tersebut memiliki peluang dan kekuatan sehingga dapat memanfaatkan peluang yang ada. Strategi yang harus diterapkan dalam kondisi ini adalah mendukung kebijakan pertumbuhan yang agresif (Growth oriented strategy).

2. Kuadran II (Strategi ST/Diversifikasi)

Meskipun menghadapi berbagai ancaman, perusahaan ini masih memiliki kekuatan dari segi internal. Strategi yang harus diterapkan adalah menggunakan kekuatan untuk memanfaatkan peluang jangka panjang dengan cara strategi diversifikasi (produk atau pasar).

3. Kuadran III (Strategi WO/Pemanfaatan Peluang/Turn around)

Perusahaan menghadapi peluang pasar yang sangat besar, tetapi dilain pihak, ia menghadapi beberapa kendala/kelemahan internal. Kondisi bisnis kuadran 3 ini mirip dengan Question Mark pada BCG matrik. Fokus strategi perusahaan ini adalah meminimalkan masalahmasalah internal perusahaan sehingga dapat merebut peluang pasar yang lebih baik. Misalnya, Apple menggunakan strategi peninjauan kembali teknologi yang dipergunakan dengan cara menawarkan produk-produk baru dalam industi microcomputer.

4. Kuadran IV (Strategi WT/Defensif)

Ini merupakan situasi yang sangat tidak menguntungkan, perusahaan tersebut menghadapi berbagai ancaman dan kelamahan internal. Strategi yang diambil adalah defensif, penciutan atau likuidasi. 


\section{HASIL PENELITIAN}

Penerbitan Blue Sukuk merupakan salah satu rencana Pemerintah dalam rangka melakukan diversifikasi instrumen pembiayaan APBN dan mendukung program pembangunan nasional jangka panjang. Program ini merupakan kebijakan pemerintah dalam mengupayakan terjadinya pertumbuhan ekonomi dan kesejahteraan rakyat secara adil, merata, dan berkelanjutan. Sukuk Biru berperan dalam pembiayaan pembangunan infrastruktur khususnya yang berkaitan dengan sektor kelautan (maritim). Berkaitan dengan hal tersebut, pada tahun 2011 pemerintah telah menerbitkan Peraturan Pemerintah tentang Pembiayaan Proyek Melalui Penerbitan Sukuk Negara (SBSN) yaitu Peraturan Pemerintah Nomor 56 Tahun 2011 Tentang Pembiayaan Proyek Melalui Penerbitan Sukuk Negara (SBSN). Peraturan ini merupakan wujud operasionalisasi dari aturan yang lebih tinggi yaitu Undang-Undang Nomor 19 Tahun 2008 tentang Surat Berharga Syariah Negara. Pada Undang-Undang tersebut di pasal 4 disebutkan bahwa tujuan penerbitan SBSN adalah untuk pembiayaan APBN termasuk di dalamnya pembiayaan proyek.

\subsection{Pembahasan Metode RIA}

\subsubsection{Menjawab Sepuluh Pertanyaan RIA}

Analisis RIA dilakukan dengan menggunaakan tahap-tahap atau langkah-langkah umum yang digunakan oleh OECD. Langkah-langkah ini meliputi menjawab sepuluh pertanyaan dasar RIA dan melakukan analisis RIA sesuai dengan proses sistematis yang telah ditetapkan.

Sepuluh pertanyaan dan jawaban disajikan pada Tabel berikut ini.

\begin{tabular}{|c|c|c|}
\hline No. & Pertanyaan & Jawaban \\
\hline 1. & $\begin{array}{l}\text { Apakah } \\
\text { masalahnya } \\
\text { dengan benar } \\
\text { telah } \\
\text { didefinisikan? }\end{array}$ & 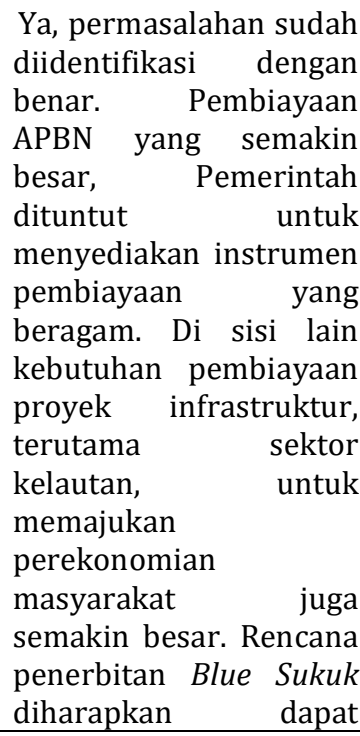 \\
\hline
\end{tabular}

\begin{tabular}{|c|c|c|}
\hline & & $\begin{array}{l}\text { memberi solusiatas dua } \\
\text { permasalahan tersebut. }\end{array}$ \\
\hline 2. & $\begin{array}{l}\text { Apakah } \\
\text { tindakan } \\
\text { pemerintah } \\
\text { sudah tepat? }\end{array}$ & $\begin{array}{l}\text { Ya, } \\
\text { Pemerintah sudah tepat. } \\
\text { Penerbitan UU Nomor } \\
19 \text { Tahun } 2008 \text { dan PP } \\
\text { Nomor 56 Tahun } 2011 \\
\text { yang bertujuan } \\
\text { mengatur penerbitan } \\
\text { Sukuk Negara dapat } \\
\text { menjadi solusi untuk } \\
\text { pembiayaan APBN } \\
\text { termasuk pembiayaan } \\
\text { proyek. }\end{array}$ \\
\hline 3. & $\begin{array}{l}\text { Apakah } \\
\text { regulasi yang } \\
\text { ada } \\
\text { merupakan } \\
\text { yang terbaik } \\
\text { untuk langkah } \\
\text { pemerintah }\end{array}$ & $\begin{array}{l}\text { UU Nomor } 19 \text { Tahun } \\
2008 \text { dan PP Nomor } 56 \\
\text { Tahun } 2011 \text { merupakan } \\
\text { salah satu regulasi } \\
\text { terbaik } \\
\text { mendorong diversifikasi } \\
\text { instrumen pembiayan } \\
\text { untuk pembangunan } \\
\text { infrastruktur } \\
\text { Indonesia. }\end{array}$ \\
\hline 4. & $\begin{array}{l}\text { Apakah ada } \\
\text { dasar } \\
\text { hukumnya } \\
\text { untuk sebuah } \\
\text { peraturan? }\end{array}$ & 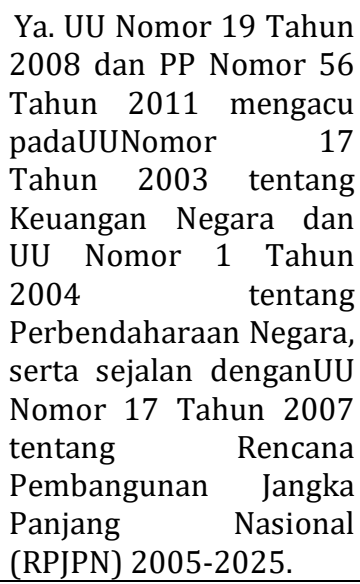 \\
\hline 5. & $\begin{array}{l}\text { Berapa } \\
\text { tingkatan } \\
\text { birokrasi } \\
\text { pemerintah } \\
\text { yang } \\
\text { dilibatkan } \\
\text { untuk } \\
\text { koordinasi } \\
\text { regulasi ini? }\end{array}$ & $\begin{array}{l}\text { Beberapa institusi yang } \\
\text { terkait: Kementerian } \\
\text { Keuangan, Kementerian } \\
\text { PPN/Bappenas, } \\
\text { Kementerian Kelautan, } \\
\text { Kementerian PUPPR, } \\
\text { Kementerian } \\
\text { Lingkungan Hidup dan } \\
\text { Kehutanan, } \\
\text { Kementerian ESDM. }\end{array}$ \\
\hline 6. & $\begin{array}{l}\text { Apakah } \\
\text { regulasi yang } \\
\text { ada } \\
\text { bermanfaat, } \\
\text { dibanding } \\
\text { biayanya? }\end{array}$ & $\begin{array}{l}\text { Ya. Hasil pengukuran } \\
\text { menunjukkan } \\
\text { manfaatnya lebih besar } \\
\text { dari biayanya. }\end{array}$ \\
\hline 7. & $\begin{array}{l}\text { Apakah } \\
\text { distribusi }\end{array}$ & $\begin{array}{lc}\text { Ya. Dampaknya } & \text { akan } \\
\text { dirasakan } & \text { oleh }\end{array}$ \\
\hline
\end{tabular}




\begin{tabular}{|c|c|c|}
\hline & $\begin{array}{l}\text { akan dampak } \\
\text { nya } \\
\text { transparan di } \\
\text { masyarakat? } \\
\end{array}$ & $\begin{array}{l}\text { masyarakat di daerah } \\
\text { pesisir yang diharapkan } \\
\text { dapat meningkatkan } \\
\text { taraf hidupnya. }\end{array}$ \\
\hline 8. & $\begin{array}{l}\text { Apakah } \\
\text { peraturan } \\
\text { tersebut jelas, } \\
\text { konsisten, } \\
\text { dipahami dan } \\
\text { diakses oleh } \\
\text { pengguna? }\end{array}$ & $\begin{array}{l}\text { Aturan penerbitan Blue } \\
\text { Sukuk dapat mengacu ke } \\
\text { UU Nomor 19 Tahun } \\
2008 \text { dan PP Nomor } 56 \\
\text { Tahun 2011. Peraturan } \\
\text { tersebut sudah } \\
\text { diiimplementasikan } \\
\text { sejak beberapa tahun } \\
\text { lalu dan sangat mudah } \\
\text { dipahami serta diakses } \\
\text { oleh para pengguna. }\end{array}$ \\
\hline 9. & $\begin{array}{l}\text { Apakah semua } \\
\text { pihak yang } \\
\text { ber- } \\
\text { kepentingan } \\
\text { memiliki } \\
\text { kesempatan } \\
\text { yang sama } \\
\text { untuk me- } \\
\text { nyampaikan } \\
\text { pandangan } \\
\text { mereka? }\end{array}$ & $\begin{array}{l}\text { Ya. Semua pihak } \\
\text { terutama } \\
\text { Kementerian/Lembaga } \\
\text { dapat memiliki } \\
\text { kesempatan yang sama } \\
\text { untuk mengajukan } \\
\text { pembiayaan melalui } \\
\text { penerbitan Blue Sukuk. }\end{array}$ \\
\hline 10. & $\begin{array}{l}\text { Bagaimana } \\
\text { kepatuhan } \\
\text { akan regulasi } \\
\text { itu dapat } \\
\text { dicapai? }\end{array}$ & 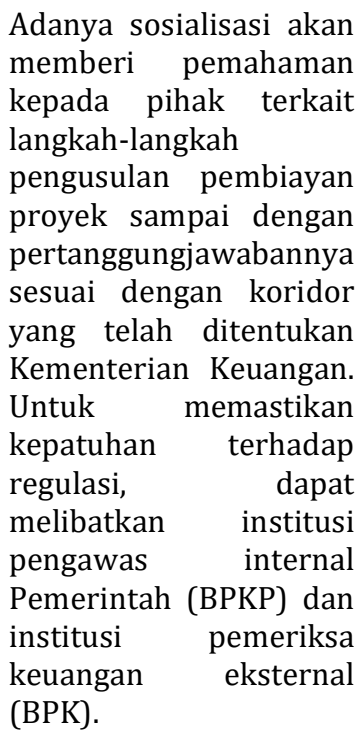 \\
\hline
\end{tabular}

\subsubsection{Analisis Regulatory Impact Assesment}

Proses sistematis RIA dalam menganalisis serta mengkomunikasikan dampak yang ada dari peraturan baru meliputi hal-hal sebagai berikut:

\section{1) Rumusan Masalah}

Rumusan masalah yang diharapkan dapat terselesaikan dengan implementasi penerbitan Sukuk Biru diantaranya adalah:

a. Apakah Sukuk Biru dapat membantu Pemerintah dalam menyediakan jenis underlying asset baru yang diperlukan dalam penerbitan Sukuk Negara seiring dengan meningkatnya jumlah penerbitan Sukuk Negara?

b. Apakah penerbitan Blue Sukuk dapat membantu pembangunan infrastruktur sektor maritim?

c. Apakah penerbitan Blue Sukuk dapat membantu Pemerintah dalam mencapai targettarget Sustainable Development Goals (SDGs) yang ditetapkan oleh PBB dan disepakati oleh anggotanya termasuk Indonesia untuk dicapai hingga tahun 2030 nanti?

2) Identifikasi Tujuan

Tujuan yang ingin dicapai dengan penerbitan Blue Sukuk sesuai dengan UU Nomor 19 Tahun 2008 dan PP Nomor 56 Tahun 2011, antara lain:

a. Terciptanya instrumen pembiayaan alternatif yang dapat digunakan sebagai solusi Pemerintah untuk meningkatkan peran penerbitan Sukuk Negara dalam pembangunan nasional.

b. Bertambahnya portofolio underlying asset yang dapat digunakan dalam penerbitan Sukuk Negara.

c. Menjadi salah satu solusi pembiayaan infrastruktur sektor maritim yang dapat membantu keberlangsungan sektor maritim dalam mendukung pembangunan nasional.

d. Membantu pencapaian tujuan nasional yaitu penambahan lapangan pekerjaan, pengurangan kemiskinan terutama masyarakat nelayan sekaligus tercapainya SDGs terutama pada tujuan ke 14 yang berbunyi "Konservasi dan Penggunaan Berkelanjutan dari Sumber Daya Laut dalam rangka Pembangunan Berkelanjutan".

3) Alternatif Solusi Permasalahan

Alternatif solusi untuk berbagai permasalahan tersebut di atas yaitu:

a. Pemerintah terus melakukan pengembangan instrumen yang selaras dengan amanat UU Nomor 19 Tahun 2008 dan PP Nomor 56 Tahun 2011. Pengembangan tersebut diperuntukkan bagi pembiayaan terutama yang berkaitan dengan program yang berskala nasional seperti RPJPN dan program berskala global seperti pencapaian SDGs pada tahun 2030. Blue Sukuk sangat sesuai menjadi instrumen tersebut.

b. Pemerintah tetap menggunakan instrumen pembiayaan yang ada, dengan alasan pembangunan sektor maritim sebenarnya juga merupakan bagian dari pembangunan infrastruktur nasional. Selama ini, 
pembangunan infrastruktur telah banyak menggunakan jenis Sukuk Negara Project-Based Sukuk (PBS).

4.1.3. Matriks Analisis Biaya-Manfaat Implementasi Sukuk Biru di Indonesia

Analisis Biaya-Manfaat digunakan untuk mengevaluasi efisiensi penggunaan sumbersumber ekonomi. Analisis Biaya-Manfaat atau CBA (Cost-Benefit Analysis) adalah pendekatan untuk rekomendasi kebijakan yang memungkinkan analis kebijakan untuk membandingkan dan menganjurkan suatu kebijakan dengan cara menghitung total biaya dan total manfaat dalam bentuk uang.

Analisis Biaya-Manfaat juga dapat diartikan suatu teknik yang digunakan untuk membandingkan berbagai biaya yang terkait dengan investasi dengan manfaat yang diharapkan untuk didapatkan. Faktor berwujud maupun tidak berwujud harus diperhitungkan dan dipertanggungjawabkan. Analisis Biaya-Manfaat digunakan untuk menentukan apakah suatu investasi layak dilakukan dan memberikan dasar untuk perbandingan antar proyek/investasi, untuk melihat pilihan mana yang memberikan manfaat lebih besar dibandingkan biayanya.

Analisis Biaya-Manfaat rencana penerbitan Blue Sukuk disajikan pada Tabel di bawah ini:

\begin{tabular}{|c|c|}
\hline Manfaat & Biaya \\
\hline \multicolumn{2}{|l|}{ Bagi Pemerintah } \\
\hline $\begin{array}{l}\text { - Penambahan } \\
\text { investasi baru } \\
\text { - Tambahan } \\
\text { penerimaan PPh } \\
\text { dari Sukuk Negara } \\
\text { - Nilai residu } \\
\text { infrastruktur }\end{array}$ & $\begin{array}{l}\text { - } \text { Biaya pembuatan } \\
\text { peraturan baru } \\
\text { - } \text { Biaya pemasaran } \\
\text { - } \text { Biaya sosialisasi } \\
\text { - Biaya identifikasi } \\
\text { dan penyiapan } \\
\text { proyek } \\
\text { - Biaya imbalan } \\
\text { Sukuk Negara } \\
\text { - Pengembalian } \\
\text { investasi } \\
\end{array}$ \\
\hline \multicolumn{2}{|c|}{ Bagi Industri Keuangan termasuk Investor } \\
\hline $\begin{array}{l}\text { - Penerimaan } \\
\begin{array}{l}\text { imbalan } \\
\text { Negara }\end{array}\end{array}$ & - Pembayaran PPh \\
\hline
\end{tabular}

Manfaat kebijakan penerbitan Blue Sukuk dengan asumsi sebagai berikut:

- Nilai manfaat selama 5 tahun sesuai tenor Sukuk

- Daya serap Blue Sukuk setingi-tingginya sama dengan Green Sukuk pada tahun 2018 yaitu sebesar USD 1,25 miliaratau senilai Rp14.000,00 x 1.250.000.000 = Rp17,5 triliun.

- Potensi penerimaan pajak berupa PPh Final sebesar $15 \%$ dari nilai imbalan yang diberikan oleh pemerintah. Sukuk Negara yang diterbitkan di pasar domestik dengan tenor 5 tahun, rata-rata imbalan yang diberikan adalah $8,2 \%$ per tahun. Sehingga potensi penerimaan $\mathrm{PPh}$ final adalah:

\section{Imbalan Sukuk Negara}

Per Tahun $\quad$ : Rp17,5 triliun x 8,2\% = 1,435 triliun

5 l'ahun : Kp1,435 trilun x $5=$ kp7,175 triliun

Potensi Penerimaan PPh Final

Per Tahun : Rp1,135 triliun $\times 15 \%=$ Rp215,25 miliar

5 Tahun : Rp215,25 miliar x 5 = Rp1,077 triliun

- Nilai residu infrastruktur yang dibangun dengan Blue Sukuk, dengan asumsi infrastruktur dapat digunakan sampai dengan 20 tahun dan penyusutan menggunakan metode garis lurus:

\section{Nilai Penyusutan}

Per Tahun : Rp17,5 triliun : $20=$ Rp875 miliar

5 tahun : Kp875 miliar $\times 5=\mathrm{kp4}, 375$ triliun

\section{Nilai Residu Setelah 5 Tahun}

Rp17,5 Triliun $-\mathrm{Rp} 4,375$ triliun = Rp13,125 triliun

Biaya atas kebijakan penerbitan Blue Sukuk diantaranya:

- Biaya konsultan hukum (KH) internasional dan domestik:

Rp 700 juta (KH internasional) + Rp 250 juta (KH domestik) $=$ Rp950 juta

- Biaya pemasaran sebesar 45 basis points dari hasil penerbitan $(0,45 \%)$ :

Rp17,5 triliun x 0,45\% = Rp78,75 miliar

- Biaya sosialisasi, mengambil rata-rata biaya yang dikeluarkan untuk melakukan investor gathering di 10 kota $=$ Rp1,4 miliar

- Biaya identifikasi dan penyiapan proyek adalah biaya rapat dengan kemeterian/lembaga terkait, diasumsikan $10 \mathrm{x}$ rapat $=\mathrm{Rp} 100$ juta

- Biaya audit kesesuaian dengan Blue Economic Platform = USD 10.000 atau Rp140.000.000,00

- Biaya imbalan Blue Sukuk, berdasarkan perhitungan sebelumnya senilai: Rp7,175 triliun ( 5 tahun)

- Nilai pengembalian investasi yaitu senilai investasi dari investor: Rp17,5 triliun 
Nilai biaya dan manfaat tersebut kemudian disajikan dalam matriks berikut ini:

Tabel 8.Matriks Biaya dan Manfaat Blue Sukuk Selama 5 Tahun

\begin{tabular}{|c|c|c|c|}
\hline Manfaat & $\begin{array}{l}\text { Nilai (juta } \\
\text { rupiah) }\end{array}$ & Biaya & $\begin{array}{c}\text { Nilai } \\
\text { (juta } \\
\text { rupiah) }\end{array}$ \\
\hline \multicolumn{4}{|l|}{ Bagi Pemerintah } \\
\hline $\begin{array}{l}\text { - Penambahan } \\
\text { investasi } \\
\text { baru }\end{array}$ & 17.500 .000 & $\begin{array}{l}\text { - } \begin{array}{l}\text { Biaya } \\
\text { pembuatan } \\
\text { peraturan } \\
\text { baru }\end{array} \\
\end{array}$ & 950 \\
\hline $\begin{array}{l}\text { - } \text { Tambahan } \\
\text { penerimaan } \\
\text { PPh dari } \\
\text { Sukuk } \\
\text { Negara } \\
\end{array}$ & 1.077 .000 & $\begin{array}{l}\text { - } \text { Biaya } \\
\text { pemasaran }\end{array}$ & 78.750 \\
\hline \multirow[t]{5}{*}{$\begin{array}{l}\text { - Nilai residu } \\
\text { infrastruktur }\end{array}$} & \multirow[t]{5}{*}{13.125 .000} & 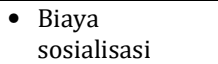 & 1.400 \\
\hline & & $\begin{array}{l}\text { - } \text { Biaya } \\
\text { identifikasi } \\
\text { dan penyiapan } \\
\text { proyek }\end{array}$ & 100 \\
\hline & & $\begin{array}{l}\text { - Biaya imbalan } \\
\text { Sukuk Negara }\end{array}$ & 7.175 .000 \\
\hline & & $\begin{array}{l}\text { - Biaya audit } \\
\text { Blue Economic } \\
\text { Platform }\end{array}$ & 140 \\
\hline & & $\begin{array}{l}\text { - Pengembalian } \\
\text { investasi }\end{array}$ & 17.500 .000 \\
\hline \multicolumn{4}{|c|}{ Bagi Industri Keuangan termasuk Investor } \\
\hline $\begin{array}{l}\text { - Penerimaan } \\
\text { berupa } \\
\text { imbalan } \\
\text { Sukuk } \\
\text { Negara } \\
\end{array}$ & 7.175 .000 & $\begin{array}{l}\text { - Pembayaran } \\
\text { PPh }\end{array}$ & 1.077 .000 \\
\hline \multicolumn{2}{|c|}{ Total Manfaat Rp38.877.000 } & \multicolumn{2}{|c|}{ Total Biaya Rp25.833.340 } \\
\hline
\end{tabular}

Berdasarkan hasil perhitungan pada Tabel 8, maka BCR penerbitan Blue Sukuk adalah:

$\mathrm{BCR}=\frac{\text { Total Manfaat }}{\text { Total Biaya }}$

$\mathrm{BCR}=\frac{R p 38 \cdot 877 \cdot 000 \cdot 000 \cdot 000}{R p 25 \cdot 833 \cdot 340.000 .000}=1,507$

Dengan demikian, nilai BCR> 1 maka penerbitan Blue Sukuk sebenarnya layak untuk diimplementasikan menjadi sebuah kebijakan.

\subsubsection{Konsultasi Publik}

Konsultasi dilakukan untuk memperoleh alternatif yang terbaik dengan melibatkan para pihak terkait (involving stakeholders). Konsultasi publik dilakukan melalui Focus Group Discussion (FGD) dan rapat bersama dengan melibatkan:

1. Pembuat kebijakan (BAPPENAS dan Kementerian Keuangan);

2. Penerbit Sukuk Negara (DJPPR, Kementerian Keuangan); dan

3. Penerima dampak kebijakan (masyarakat nelayan dan investor).
Konsultasi kepada publik perlu dilakukan karena berdasarkan prinsip, bahwa:

1. Pengambilan kebijakan strategis sejatinya melibatkan seluruh pihak terkena dampak dalam proses negosiasi dan konsultasi yang setara.

2. Pelibatan seluruh pihak yang terkena dampak berpotensi meningkatkan kualitas manfaat yang diterima publik karena implementasi kebijakan tersebut.

Sehubungan dengan kendala kesibukan dan keterbatasan waktu masing-masing pihak, maka diskusi dilakukan berdasarkan kelompokkelompok homogen saja. Misalnya, untuk membahas manfaat penerbitan Blue Sukuk pada sektor maritim dilakukan diskusi dengan para pejabat di Kementerian Kelautan dan Perikanan. Untuk mengetahui pandangan dari masing-masing kelompok terhadap permasalahan yang sama, maka dapat diberikan pertanyaan dengan tema yang sama.

\subsubsection{Memilih Alternatif Terbaik}

Setelah dilakukan analisis penerbitan Blue Sukuk dengan menggunakan metode RIA sebagaimana terdapat pada bagian 4.1.3., dengan hasil nilai BCR> 1 maka penerbitan Blue Sukuk sebenarnya layak untuk diimplementasikan menjadi sebuah kebijakan.

\subsection{Pembahasan Metode SWOT Rencana Penerbitan Blue Sukuk}

\subsubsection{Kekuatan (Strength)}

Berdasarkan hasil wawancara, beberapa kekuatan yang dimiliki diantaranya:

a. Dukungan kebijakan: Pemerintah mendukung penuh penerbitan Blue Sukuk sebagai sarana diverfisikasi pembiayaan dan intrumen pembiayaan pembangunan. Hal ini sejalan dengan Strategi Pengelolaan Utang Negara tahun 2018 yang menyebutkan bahwa Pemerintah terus melakukan upaya diversifikasi instrumen pembiayaan dalam rangka mengelola biaya dan risiko pembiayaan.

b. Jaminan Pemerintah kepada investor: Pemerintah melalui Undang-Undang SBSN memberikan jaminan keamanan investasi kepada para investor Sukuk Negara. Hal ini memberikan rasa aman bagi para investor SBSN bahwa investasinya pada SBSN mendapat jaminan dari Pemerintah secara penuh.

c. Jaringan pemasaran yang cukup luas: Pemerintah telah menerbitkan Sukuk Negara sejak tahun 2008 dan telah memiliki jaringan pemasaran yang luas di pasar keuangan 
domestik maupun global yang dapat menjadidaya dukung dalam penerbitan Blue Sukuk.

\subsubsection{Kelemahan (Weakness)}

Beberapa kelemahan yang dimiliki diantaranya:

1. Belum adanya peraturan operasional di tingkat eselon I (peraturan Direktur Jenderal). Peraturan ini diperlukan sebagai petunjuk tingkat operasional untuk menentukan siapa melakukan apa.

2. Belum adanya prinsip-prinsip yang mengatur instrumen pembiayaan yang dikategorikan sesuai/tidak dengan prinsip Blue Economy. Pemerintah perlu membuat framework tersebut bekerja sama dengan berbagai instansi terkait termasuk lembaga internasional yang membidangi hal tersebut. Proses ini juga memerlukan waktu yang tidak singkat.

3. Koordinasi internal pada level antar Kementerian/Lembaga memerlukan waktu yang tidak singkat. Kesibukan para pengambil kebijakan di Kementerian/Lembaga merupakan salah satu kelemahan untuk melakukan koordinasi dalam rangka persiapan penerbitan Blue Sukuk.

\subsubsection{Peluang (Opportunities)}

Beberapa peluang yang dimiliki diantaranya:

1. Keperluan instrumen pembiayaan untuk pembangunan berbagai proyek infrastruktur, terutama berkaitan dengan sektor maritim, masih sangat besar. Indonesia merupakan negara berkembang menuju negara maju. Saat ini pembangunan infrastruktur sedang ditingkatkan agar memberi manfaat bagi pertumbuhan ekonomi, pelayanan kepada masyarakat dan kesejahteraannya. Kebutuhan pembangunan infrastruktur yang sangat banyak ini menjadi peluang untuk melakukan pembiayaan melalui Blue Sukuk, khususnya bidang infrastruktur yang berkaitan dengan sektor maritim.

2. Pasar modal dan pasar keuangan selalu menunggu instrumen baru dari Pemerintah. Instrumen keuangan ini sangat bermanfaat untuk pengembangan pasar keuangan di Indonesia yang masih sangat dangkal. Secara umum, kondisi pasar keuangan di Indonesia masih memerlukan instrumen investasi yang dapat menjadi pendorong pengembangan pasar keuangan itu sendiri (financial deepening).

3. Dukungan industri keuangan domestik maupun internasional dalam memasarkan produk dari Pemerintah. Pelaku pasar keuangan senantiasa menunggu instrumen investasi yang diterbitkan oleh Pemerintah. Hal ini disebabkan oleh faktor keamanan berinvestasi dan kecenderungan tingkat imbal hasil yang diberikan oleh Pemerintah dinilai cukup tinggi bila dibandingkan dengan negara-negara satu level dengan Indonesia.

\subsubsection{Ancaman (Threats)}

Beberapa ancaman yang dimiliki diantaranya:

1. Masyarakat belum paham dengan Blue Sukuk. Kurangnya pemahaman masyarakat (termasuk institusi) terhadap Blue Sukuk dapat menjadi sebuah ancaman. Hal ini berkaitan dengan daya serap investor terhadap Blue Sukuk. Jika investor belum memahami Blue Sukuk maka dikhawatirkan investor tidak tertarik berinvestasi pada Blue Sukuk dan berdampak pada minimnya dana yang diperoleh dari investasi masyarakat.

2. Kementerian/Lembaga tidak tertarik menggunakan mekanisme pembiayaan Blue Sukuk. Kurangnya ketertarikan Kementerian/Lembaga dalam menggunakan pembiayaan melalui mekanisme Blue Sukuk dapat menyebabkan jumlah proyek/infrastruktur yang akan dibangun dengan pembiayaan Blue Sukuk menjadi sangat sedikit. Padahal secara keekonomian, pembiayaan melalui penerbitan Sukuk sebaiknya mencapai nilai triliunan rupiah.

3. Kondisi perekonomian dunia yang mengalami stagnasi dapat menjadi ancaman bagi penerbitan Blue Sukuk terutama untuk penerbitan di pasar internasional.

\subsubsection{Rancangan SWOT}

Selanjutnya, dengan analisis SWOT dibandingkan antara faktor eksternal berupa peluang (opportunity) dan ancaman (threat) dengan faktor internal yaitu kekuatan (strenght) dan kelemahan (weakness). Faktor internal diperoleh dari data lingkungan Pemerintah (Kementerian Keuangan), seperti laporan keuangan, kegiatan operasional, kegiatan pemasaran, dan data staf atau pejabat. Sedangkan faktor eksternal diperoleh dari lingkungan di luar institusi, seperti analisis pasar, industri keuangan, komunitas, agen penjual, institusi di luar Kementerian Keuangan, dan analisis kelompok (kepentingan tertentu). 


\begin{tabular}{|c|c|c|}
\hline \multicolumn{3}{|c|}{ Tabel 9.Matriks EFAS Dan IFAS } \\
\hline & $\begin{array}{l}\text { Kekuatan } \\
\text { (Strenght) }\end{array}$ & $\begin{array}{l}\text { Kelemahan } \\
\text { (Weakness) }\end{array}$ \\
\hline EFAS & $\begin{array}{l}\text { 1. Dukungan } \\
\text { kebijakan } \\
\text { 2. Jaminan } \\
\text { Pemerintah. } \\
\text { 3. Jaringan } \\
\text { pemasaran luas. }\end{array}$ & $\begin{array}{l}\text { 1. Belum } \\
\text { adanya } \\
\text { peraturan } \\
\text { operasional } \\
\text { 2. Belum blue } \\
\text { framework } \\
\text { 3. Sulitnya } \\
\text { koordinasi } \\
\text { internal. }\end{array}$ \\
\hline $\begin{array}{c}\text { Peluang } \\
\text { (Opportunities) }\end{array}$ & So & Wo \\
\hline $\begin{array}{l}\text { 1. Keperluan } \\
\text { pembiayaan } \\
\text { sektor maritim, } \\
\text { sangat besar. }\end{array}$ & $\begin{array}{lr}\text { Identifikasi } & \text { proyek } \\
\text { dan daya serap } \\
\text { pasar keuangan } \\
\text { domestik dan }\end{array}$ & $\begin{array}{l}\text { Pemerintah } \\
\text { menyusun } \\
\text { peraturan yang } \\
\text { diperlukan }\end{array}$ \\
\hline $\begin{array}{l}\text { 2. Pasar modal } \\
\text { dan pasar } \\
\text { keuangan } \\
\text { menunggu } \\
\text { instrumen } \\
\text { Pemerintah. } \\
\text { 3. Dukungan } \\
\text { industri } \\
\text { keuangan } \\
\text { domestik } \\
\text { maupun } \\
\text { internasional. }\end{array}$ & global & $\begin{array}{l}\text { untuk legalitas } \\
\text { penerbitan } \\
\text { Blue Sukuk }\end{array}$ \\
\hline $\begin{array}{l}\text { Ancaman } \\
\text { (Threats) }\end{array}$ & ST & WT \\
\hline $\begin{array}{l}\text { 1. Masyarakat } \\
\text { belum } \\
\text { memahami } \\
\text { Blue Sukuk } \\
\text { 2. Kementerian/ } \\
\text { Lembaga tidak } \\
\text { tertarik } \\
\text { mekanisme } \\
\text { Blue Sukuk } \\
\text { 3. Kondisi } \\
\text { perekonomian } \\
\text { dunia yang } \\
\text { mengalami } \\
\text { resesi } \\
\end{array}$ & \begin{tabular}{l}
\multicolumn{2}{l}{ Melakukan } \\
workshop dengan \\
Kementerian/Lem \\
bagar terkait, \\
sosialisasi kepada \\
industri keuangan \\
dan investor \\
domestik, \\
termasuk \\
Dealers/Lead \\
Managers.
\end{tabular} & $\begin{array}{l}\text { Melakukan } \\
\text { persiapan } \\
\text { internal yang } \\
\text { mendukung } \\
\text { penerbitan } \\
\text { Blue Sukuk } \\
\text { serta } \\
\text { memantau } \\
\text { kondisi } \\
\text { perekonomian } \\
\text { domestik } \\
\text { maupun global }\end{array}$ \\
\hline
\end{tabular}

4.2.6. Pilihan Strategi yang Digunakan

1. Strategi SO (Strength-Opportunity), strategi menggunakan kekuatan internal untuk meraih peluang-peluang yang ada di luar.

Identifikasi daya serap pasar keuangan domestik dan global berkaitan dengan rencana penerbitan Blue Sukuk.

2. Strategi WO (Weakness-Opportunity), strategi ini bertujuan untuk memperkecil kelemahankelemahan internal dengan memanfaatkan peluang-peluang.

Pemerintah segera menyusun peraturan yang diperlukan untuk legalitas penerbitan Blue Sukuk dengan melibatkan para pemangku kebijakan, misal: industri keuangan, investor dan Kementerian/Lembaga.

3. Strategi ST (Strength-Threat), strategi untuk menghindari atau mengurangi dampak dari ancaman-ancaman eksternal.
Melakukan workshop dengan

Kementerian/Lembaga terkait, sosialisasi kepada industri keuangan dan investor domestik, serta menyampaikan rencana penerbitan Blue Sukuk kepada investor global melalui para Dealers/Lead Managers.

4. Strategi WT (Weakness-Threat), strategi ini merupakan teknik untuk bertahan dengan cara mengurangi kelemahan internal serta menghindari ancaman.

Melakukan persiapan internal yang mendukung penerbitan Blue Sukuk serta memantau kondisi perekonomian domestik maupun global.

\section{SIMPULAN DAN SARAN}

\subsection{Simpulan}

1. Berdasarkan hasil analisis menggunakan metode Regulatory Impact Analysis (RIA), diketahui bahwa manfaat penerbitan Blue Sukuk lebih besar daripada biaya yang ditimbulkan (nilai BCR $>1$ ). Dengan begitu, Blue Sukuk memiliki potensi sebagai kebijakan yang layak diimplementasikan.

2. Hasil pengujian dengan alat analisis lainnya yaitu Analisis Strength, Weakness, Opportunity, and Threat (SWOT). Berdasarkan analisis SWOT yang telah dilakukan, maka pilihan strategi yang digunakan yaitu:

a. Strategi SO (Strength-Opportunity), yaitu dengan melakukan identifikasi proyek dan daya serap pasar keuangan domestik dan global berkaitan dengan rencana penerbitan Blue Sukuk.

b. Strategi WO (Weakness-Opportunity), kegiatan yang dilakukan yaitu Pemerintah segera menyusun peraturan yang diperlukan untuk legalitas penerbitan Blue Sukuk dengan melibatkan para pemangku kebijakan, misal: industri keuangan, investor dan Kementerian/Lembaga.

c. Strategi ST (Strength-Threat), kegiatan yang dilakukan yaitu workshop dengan Kementerian/Lembaga terkait, sosialisasi kepada industri keuangan dan investor domestik, serta menyampaikan rencana penerbitan Blue Sukuk kepada investor global melalui para Dealers/Lead Managers.

d. Strategi WT (Weakness-Threat), kegiatan yang dilakukan yaitu persiapan internal yang mendukung penerbitan Blue Sukuk serta memantau kondisi perekonomian domestik maupun global. 


\subsection{Saran}

Berdasarkan kajian yang telah dilakukan, maka saran-saran yang dapat diberikan sebagaimana disebutkan berikut ini.

1. Meskipun penerbitan Blue Sukuk layak untuk diimplementasikan, namun terdapat beberapa hal yang perlu segera dilakukan oleh Pemerintah, diantaranya yaitu:

a. Kementerian Keuangan perlu menyiapkan kerangka aturan terkait penerbitan Blue Sukuk. Walaupun telah diterbitkan UndangUndang dan Peraturan Pemerintah terkait dengan pembiayaan proyek menggunakan Sukuk Negara, Kementerian Keuangan perlu menyiapkan aturan mengenai Blue Sukuk Framework. Dalam menyiapkan kerangka aturan ini, Kementerian Keuangan dapat melibatkan unsur Pemerintahan lainnya atau Non Government Organization (NGO) baik domestik maupun internasional agar dapat memberikan masukan terhadap Blue Sukuk Framework. Pedoman ini perlu disiapkan untuk membatasi kriteria apa saja yang dapat dibiayai dengan Blue Sukuk.

b. Seleksi dan penilaian proyek. Langkah selanjutnya, Pemerintah dapat melakukan seleksi proyek yang akan dibiayai dengan penerbitan Blue Sukuk. Dalam tahap awal penerapan Blue Sukuk, Pemerintah dapat mengambil proyek-proyek yang sudah terdapat dapat APBN tahun berjalan. Proyek-proyek tersebut selanjutnya dilakukan penilaian (assessment) terutama kesesuaiannya dengan Blue Economy Platform atau standar internasional lainnya dalam penerbitan Blue Bonds. Evaluasi proyek, seperti halnya dalam penerbitan Green Sukuk, dapat dilakukan oleh pihak eksternal (independent reviewer) yang dapat menyediakan petunjuk dan dukungan untuk melakukan evaluasi proyek.

2. Saran selanjutnya, Pemerintah dapat menerbitkan Blue Sukuk untuk investor domestik terlebih dahulu sebelum investor global. Pertimbangannya adalah kondisi perekonomian dunia yang sedang menghadapi resesi berpengaruh terhadap preferensi investor dalam berinvestasi. Dalam kondisi bearish seperti saat ini, risiko investasi mengalami peningkatan, sehingga dikhawatirkan imbal hasil yang diminta akan semakin tinggi diiringi risiko lainnya seperti risiko nilai tukar. Sementara, tingkat acuan imbalan (BI7-Day Repo Rate) saat ini cenderung rendah sehingga berdampak pada biaya imbalan Sukuk Negara yang lebih rendah pula.

\section{IMPLIKASI DAN KETERBATASAN}

Penelitian ini belum membandingkan biaya dan manfaat penerbitan Blue Sukuk dengan instrumen pembiayaan lain yang dimiliki oleh Pemerintah seperti: pinjaman dan hibah, Surat Utang Negara (SUN), dan instrumen Sukuk Negara lainnya. Oleh karena itu, peneliti menyarankan pada penelitian selanjutnya dapat melakukan analisis biaya dan manfaat yang membandingkan pembiayaan sektor kelautan (maritim) dengan menggunakan berbagai instrumen pembiayaan eksisting yang telah dimiliki oleh Pemerintah.

\section{PENGHARGAAN}

Peneliti ingin menyampaikan ucapan terima kasih kepada para pihak yang telah memberikan kesempatan untuk menyelesaikan penelitian ini,

1. Ibu Heni Kartikawati, S.Psi., M.A., M.Psi, Kepala Pusdiklat Keuangan Umum BPPK,

2. Bapak Prof. Dr. Muhammad Firdaus, M.S., Guru Besar Fakultas Ekonomi dan Manajemen Universitas IPB,

3. Ibu Dwi Irianti Hadiningdyah, S.H., M.A., Direktur Pembiayaan Syariah DJPPR.

Peneliti berharap hasil penelitian ini dapat bermanfaat bagi kebijakan pengembangan Sukuk Negara di masa mendatang.

\section{REFERENSI}

Adam, N. J., \& Thomas, A. (2004). Islamic bonds: your guide to issuin, structuring, and investing in sukuk. London: Euromoney Books.

Adrianto, L. (2015). Tata kelola kawasan konservasi perairan untuk perikanan berkelanjutan di Indonesia. Seri Publikasi PKSPL-IPB.

Anggraini, Y. (2018). Peran green sukuk dalam memperkokoh posisi Indonesia di pasar keuangan syariah global. El-Barka: Journal of Islamic Economics and Business, 1(2), 251-268.

Biro Hukum Kementerian PPN/BAPPENAS. (2011). Pengembangan dan implementasi metode regulatory impact analysis (ria) untuk menilai kebijakan (peraturan dan non peraturan) di Kementerian PPN/BAPPENAS. Jakarta: Kementerian PPN/BAPPENAS.

Choliq, A. (1999). Evaluasi proyek: edisi revisi. Jakarta: Pinir Jaya.

Direktorat Pembiayaan Syariah DJPPR Kementerian Keuangan. (2015). Sukuk negara instrumen keuangan berbasis syariah. Jakarta: Direktorat Pembiayaan Syariah DJPPR Kementerian Keuangan.

Dahuri, R. (2010). Paradigma baru pembangunan Indonesia berbasis kelautan. Orasi ilmiah 
pengukuhan guru besar tetap bidang pengelolaan sumber daya pesisir dan lautan. Fakultas Perikanan dan Ilmu Kelautan Institut Pertanian Bogor.

Dermawan, A. (2019). KKP terus kembangkan pengelolaan pulau-pulau kecil dan terluar sebagai kedaulatan bangsa. Diakses tanggal 28 Juni 2020, dari https://kkp.go.id/djprl/artikel/10236-kkpterus-kembangkan-pengelolaan-pulau-pulau-kecildan-terluar-sebagai-kedaulatan-bangsa.

Dermawan, A. (2017). Refleksi 2017 dan outlook 2018 membangun dan menjaga ekosistem laut indonesia bersama ditjen pengelolaan ruang laut. Diakses tanggal 28 Juni 2020, dari https://kkp.go.id/djprl/artikel/2798-refleksi2017-dan-outlook-2018-membangun-danmenjaga-ekosistem-laut-indonesia-bersama-ditjenpengelolaan-ruang-laut.

Hariadi, B. (2002). Akuntansi manajemen. Yogyakarta: BPFE.

Hariyanto, E. (2017a). Evaluasi kebijakan penerbitan Sukuk Negara sebagai instrumen pembiayaan APBN (1 ed.). Yogyakarta: Penerbit Gava Media.

Hariyanto, E. (2017b). Mengenal sukuk negara instrumen pembiayaan apbn dan sarana investasi masyarakat. (D. Indiahono, Ed.) (1 ed.). Yogyakarta: Penerbit Gava Media.

Ilma, A. F. N. (2017). Blue economy: kesimbangan perspektif ekonomi dan lingkungan. Jurnal Ilmu Ekonomi dan Pembangunan, 14(1), 1-10.

Niermasasi, R. (2013). Blue economy. Diakses tanggal 28 Juni 2020, dari https://www.kompasiana.com/www.rieres.com/5 55f7ff1a223bd64048b456f/blue-econom.

Kotler, P., \& Keller, K. L. (2009. Manajemen pemasaran. Jakarta: Penerbit Indeks.

Mangkoesoebroto, G. (2018). Ekonomi publik: edisi ketiga. Yogyakarta: BPFE Yogyakarta.

Manurung, M., \& Rahardja, P. (2004). Uang, perbankan, dan ekonomi moneter (kajian kontekstual Indonesia). Jakarta: Lembaga Penerbit FEUI.
Moolna, A. \& Thompson, B. S. (2018). The blue economy approach for sustainability in seychelles \& east africa. keele university institute for sustainable futures. Discussion Paper. Keele University, Keele.

OECD. (2008). Building an institutional framework for regulatory impact analysis (RIA): guidance for policy makers. Regulatory Policy Division: Directorate for Public Governance and Territorial Development.

Peraturan Pemerintah Nomor 56 Tahun 2011 Tentang Pembiayaan Proyek Melalui Penerbitan Sukuk Negara (SBSN).

Rakhmindyarto, \& Sinulingga, F. (2014). Ekonomi biru untuk maritim Indonesia yang berkelanjutan. Diakses tanggal 28 Juni 2020, dari https://www.kemenkeu.go.id/publikasi/artikeldan-opini/ekonomi-biru-untuk-maritim-indonesiayang-berkelanjutan.

Rani, F., \& Cahayasari, W. (2015). Model blue economy di kawasan asia pasifik (studi kasus: penerapan model blue economy pada industri perikanan Indonesia). Jurnal Online Mahasiswa Fakultas Ilmu Sosial Dan Ilmu Politik Universitas Riau, 2(1) 1-14.

Rangkuti, F. (2016). Analisis SWOT: teknik membedah kasus bisnis. Jakarta: Gramedia Pustaka Utama.

Sitorus, H. W. (2018). Analisis konsep blue economy pada sektor kelautan di Indonesia berdasarkan undang-undang nomor 32 tahun 2014 tentang kelautan. JOM Fakultas Hukum, 5 (2), 1-15.

Undang-Undang Nomor 19 Tahun 2008 tentang Surat Berharga Syariah Negara.

World Bank. (2018). Seychelles lounches world's first sovereign blue bond. Diakses tanggal 28 Juni 2020, dari https://www.worldbank.org/en/news/ press-release/2018/10/29/seychelles-launchesworlds-first-sovereign-blue-bond. 